\title{
Archaeological Survey and Testing in San Pedro Park (41BX19), San Antonio, Texas
}

Brett A. Houk

Department of Anthropology, Texas Tech University

Follow this and additional works at: https://scholarworks.sfasu.edu/ita

Part of the American Material Culture Commons, Archaeological Anthropology Commons, Environmental Studies Commons, Other American Studies Commons, Other Arts and Humanities Commons, Other History of Art, Architecture, and Archaeology Commons, and the United States History Commons

Tell us how this article helped you.

This Article is brought to you for free and open access by the Center for Regional Heritage Research at SFA ScholarWorks. It has been accepted for inclusion in Index of Texas Archaeology: Open Access Gray Literature from the Lone Star State by an authorized editor of SFA ScholarWorks. For more information, please contact cdsscholarworks@sfasu.edu. 


\section{Archaeological Survey and Testing in San Pedro Park (41BX19), San Antonio, Texas}

\section{Creative Commons License}

\section{(c) (1) (9)}

This work is licensed under a Creative Commons Attribution-NonCommercial 4.0 International License 


\title{
Archaeological Survey and Testing in San Pedro Park (41BX19), San Antonio, Texas
}

\author{
Brett A. Houk \\ With Contributions by \\ Barbara A. Meissner and I. Waynne Cox
}

Center for Archaeological Research The University of Texas at San Antonio Archaeological Survey Report, No. 289 1999

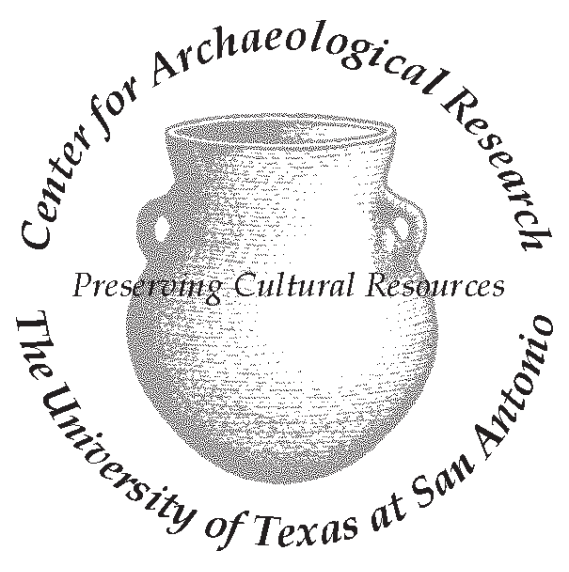




\title{
Archaeological Survey and Testing in San Pedro Park (41BX19), San Antonio, Texas
}

\author{
Brett A. Houk
}

With Contributions by Barbara A. Meissner and I. Waynne Cox

Robert J. Hard and C. Britt Bousman Principal Investigators

Texas Antiquities Permit No. 1976

Ccopyright 1999

Center for Archaeological Research

The University of Texas at San Antonio

Archaeological Survey Report, No. 289 
The following information is provided in accordance with the General Rules of Practice and Procedure, Chapter 41.11 (Investigative Reports), Texas Antiquities Committee:

1. Type of investigation: Survey and Testing

2. Project name: San Pedro Park Pond Project

3. County: Bexar

4. Principal investigators: Robert J. Hard and C. Britt Bousman

5. Name and location of sponsoring agency: City of San Antonio, Parks and Recreation Department, 115 Plaza de Armas, Suite 260, San Antonio, TX, 78283-3966

6. Texas Antiquities Permit No.: 1976

7. Published by the Center for Archaeological Research, The University of Texas at San Antonio, 6900 N. Loop 1604 W., San Antonio, Texas 78249-0658, 1999

A list of publications offered by the Center for Archaeological Research is available. Call (210) 458-4378; write to the Center for Archaeological Research, The University of Texas at San Antonio, 6900 N. Loop 1604 W., San Antonio, Texas 78249-0658; e-mail to car@lonestar.utsa.edu; or visit CAR's web site at http://www.csbs.utsa.edu/research/car/index.htm. 


\begin{abstract}
In April 1998, staff from the Center for Archaeological Research (CAR) of The University of Texas at San Antonio completed a pedestrian survey and a series of 44 shovel tests and two backhoe trenches in San Pedro Park, in San Antonio, Texas. The project was required to evaluate the potential for significant historic (including a Spanish Colonial dam and acequia) and prehistoric cultural deposits in areas to be impacted by a plan to renovate the park, including the rebuilding of a swimming pool.

The shovel tests showed that the majority of the area to be impacted by renovation was already disturbed. Areas which appear to retain undisturbed cultural deposits were identified. One backhoe trench found that the Spanish Colonial dam was probably destroyed by early twentieth-century renovations.
\end{abstract}




\section{Contents}

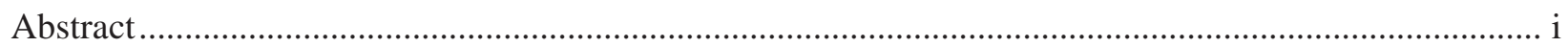

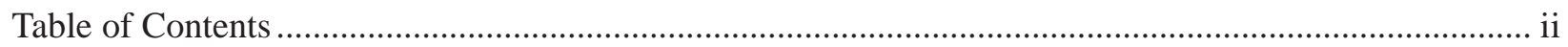

List of Figures

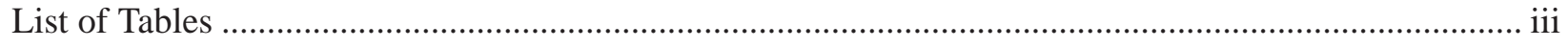

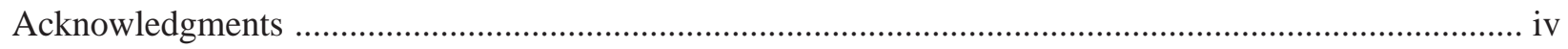

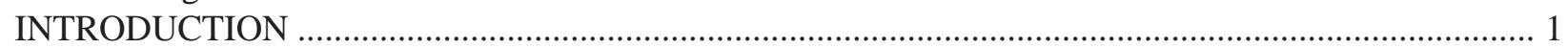

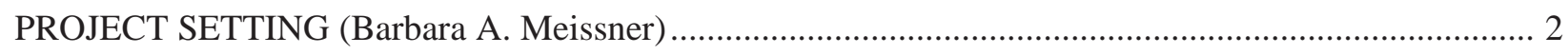

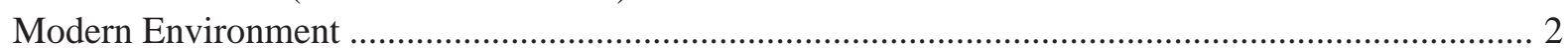

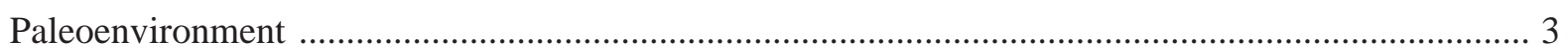

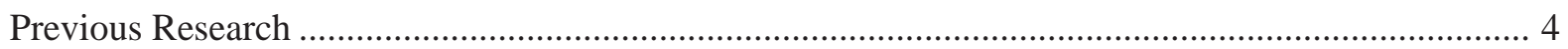

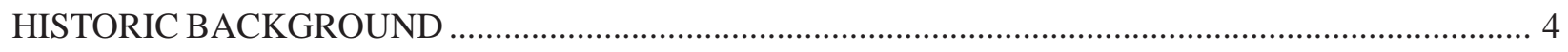

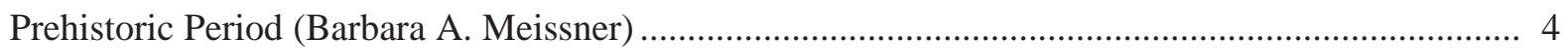

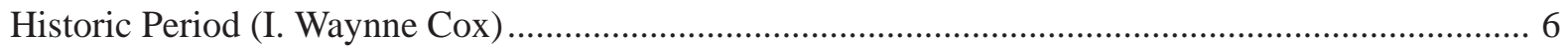

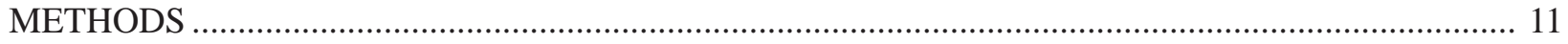

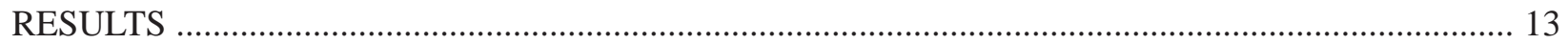

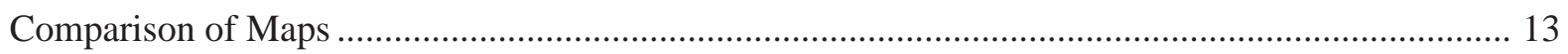

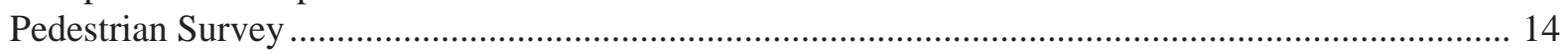

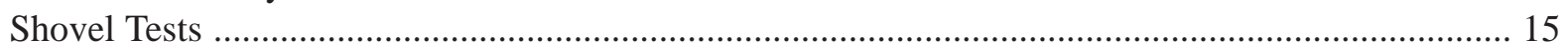

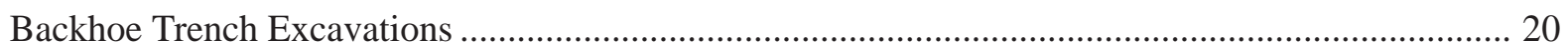

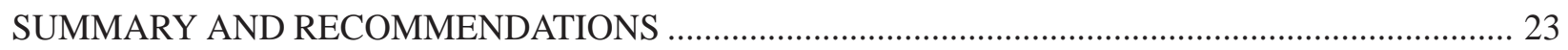

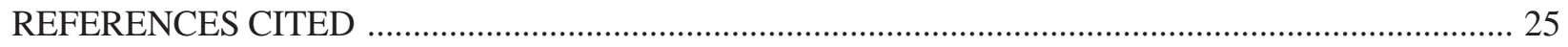

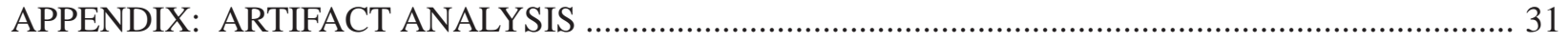

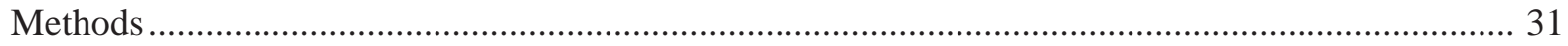

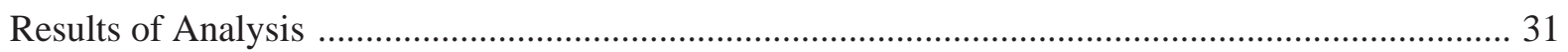




\section{Figures}

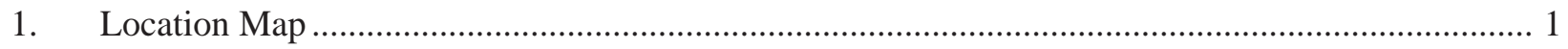

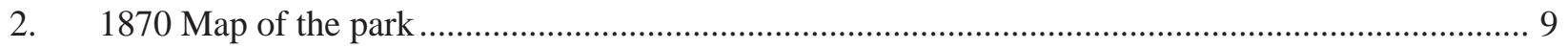

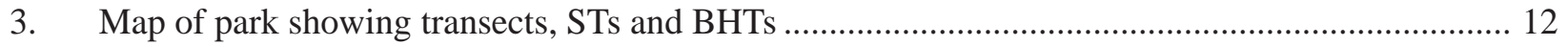

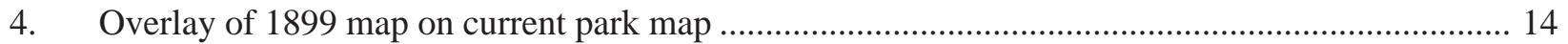

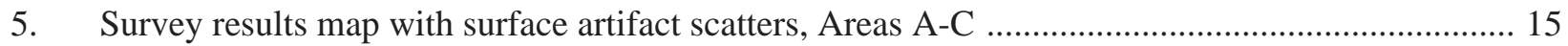

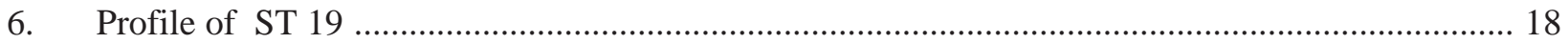

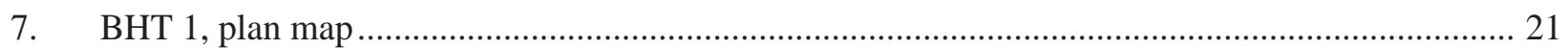

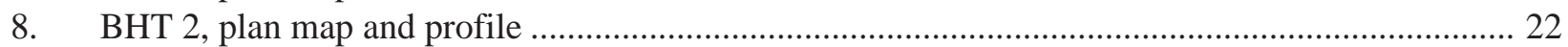

9. Map of intact prehistoric and possible historic deposit locations ............................................. 24

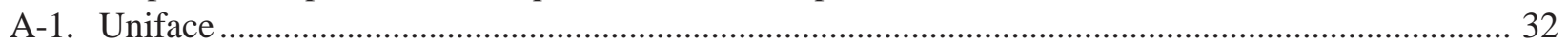

\section{Tables}

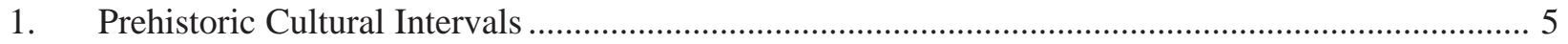

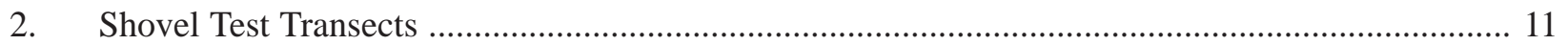

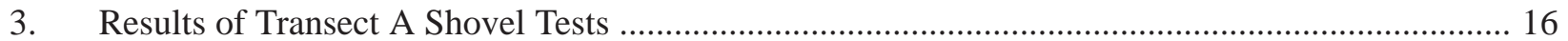

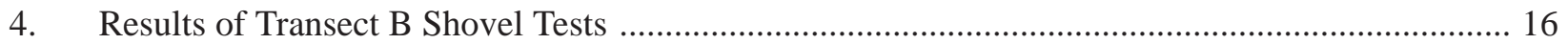

5. Results of Transect C Shovel Tests ................................................................................... 16

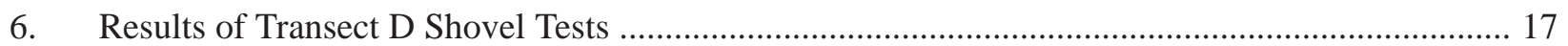

7. Results of Transect E Shovel Tests .................................................................................... 17

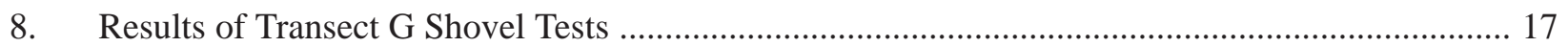

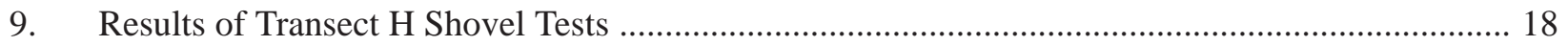

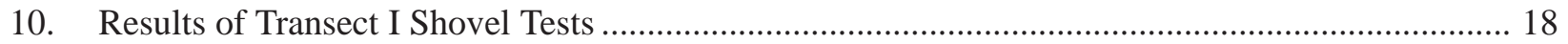

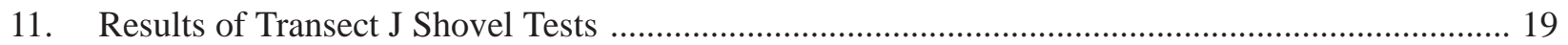

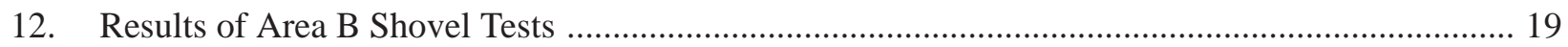

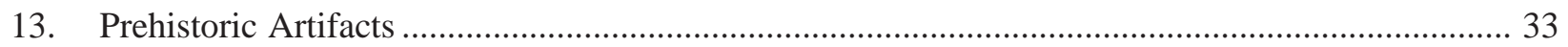




\section{Acknowledgments}

The author would like to thank Scott Stover of the City of San Antonio, Parks and Recreation Department, for his cooperation on this project.

Principal Investors for this project were Robert J. Hard and C. Britt Bousman. The project archaeologist was Brett A. Houk, who was assisted in the field by Waynne Cox, Donna Edmondson, Owen Ford, Kevin Hanselka, Chris Horrell, Kimberly Kverness, Tony Lyle, Ruth Mathews, and José Zapata. The manuscript was edited by Marcie Renner. Barbara A. Meissner drafted the figures. 
The Center for Archaeological Research (CAR) of The University of Texas at San Antonio performed an archaeological survey and limited testing project at San Pedro Park for the city of San Antonio, Parks and Recreation Department, in April 1998. San Pedro Park is the second oldest park in the United States and has been in continuous public use since 1729. Because the park is the home of San Pedro Springs, a series of natural springs which form the headwaters of San Pedro
Creek, a tributary of the San Antonio River, the area also has a long history of prehistoric use and occupation.

The 46-acre park (Figure 1) currently contains the McFarlin Tennis Center in the northeast corner, two baseball fields in the southeast corner, the San Pedro Playhouse in the northwest corner, and a pool and bathhouse near its center. These facilities are supported by a variety of parking lots, walkways, and utilities.

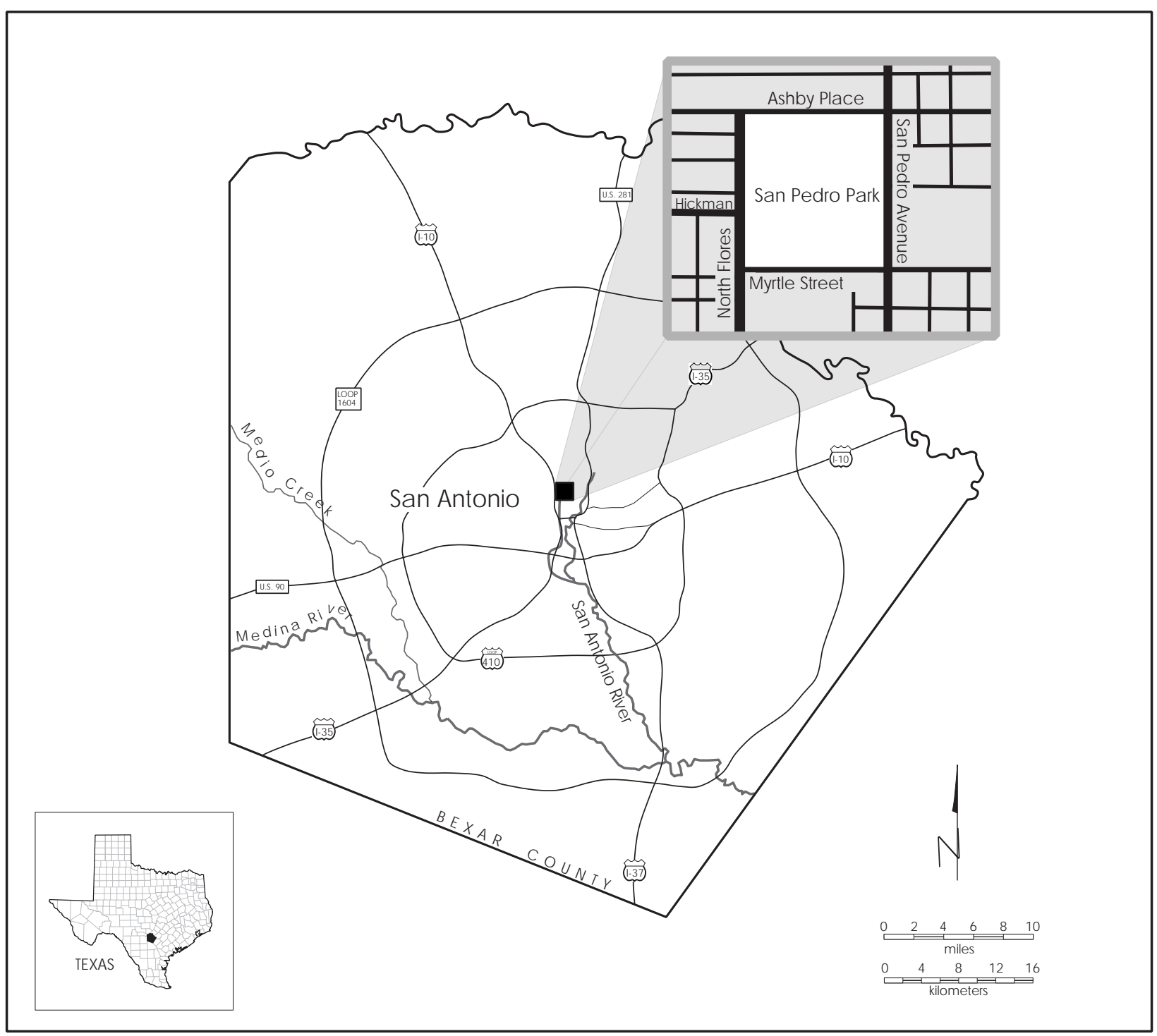

Figure 1. Project location map. 
The Parks and Recreation Department has proposed a series of infrastructure improvements to the park, including the installation of new, underground utility lines; the construction of new walkways; the removal of existing parking lots, access drives, and walkways; the renovation of the bathhouse; and the installation of a new pool/lake at the south end of the existing swimming pool.

Although the park has been subjected to serious disturbances, particularly in the last 100 years of use, previous archaeological investigations have documented intact prehistoric deposits (Meissner et al. 1998). Furthermore, important historic features, including the San Pedro and Alazán acequias, pass through the park (Meissner et al. 1998). The Texas Historical Commission (THC) recommended a surface survey of the southern two-thirds of the park, shovel testing along selected transects, and backhoe trenching in the area to be impacted by the construction of the new pool/lake. The backhoe trenching was intended to locate the original Spanish diversion dam and gate to the San Pedro Acequia.

The archaeological investigations were conducted between April 6 and April 30, 1998, under Texas Antiquities Permit 1976, issued by the THC. The principal investigator was Robert J. Hard, and the coprincipal investigator was $\mathrm{C}$. Britt Bousman. The investigations sponsored by Parks and Recreation were conducted concurrently with a separate project in the southwest corner of the park. Those investigations, sponsored by the San Antonio River Authority, are reported separately (Meissner et al. 1998).

\title{
PROJECT SETTING
}

\author{
Barbara A. Meissner
}

San Pedro Park is located between Ashby Street on the north, San Pedro Street on the east, Myrtle Street on the south, and North Flores Street on the west (Figure 1). San Pedro Springs, comprised of at least 11 major and numerous minor springs, is one of the many outlets of the Edwards Aquifer, which receives its recharge from the hills north of the city (Brune 1981:73). Until modern pumping practices lowered the level of the Edwards Aquifer, the flow of water into San Pedro Creek averaged about 200-250 liters per second.

\section{Modern Environment}

The city of San Antonio has a modified subtropical climate, with cool winters and hot summers (Taylor et al. 1991:118). Average temperatures range from 62.3 $\mathrm{F}$ in January to $94.2 \mathrm{~F}$ in August (Taylor et al. 1991:Table 11). Rainfall averages 27.89 inches but there is a great deal of variation from year to year (Norwine 1995:139). The growing season averages 275 days (Taylor et al. 1991:119).
Soils from three series occur in San Pedro Park (Taylor et al. 1991:Map 44). The northeast quarter has a Tarrent association soil. These soils are typically found on hilly areas and are dark colored, very shallow, clayey, and weakly calcareous (Taylor et al. 1991:31). The northwest corner of the park has Austin silty clay soil. This soil is found on low, broad ridge tops. It is moderately deep, dark colored, and highly calcareous (Taylor et al. 1991:10). The rest of the park is covered with Houston Black clay terrace soil. This soil is a thick, dark, calcareous clay common on terraces near major streams (Taylor et al. 1991:21).

Bexar County is located at the juncture of several major biotic and physiographic regions, providing a diverse and dynamic biological setting. Potter et al. (1995:23) note the presence of five biotic zones in the county. The northernmost is the Oak-Juniper Woodland, which covers the southern edge of the Balcones Escarpment, created by a fault zone cutting across the northern half of the county (Potter et al. 1995; Taylor et al. 1991:119). This region has been described as "canyonlands" (Potter et al. 1995:13), heavily dissected by numerous creeks and springs. Tallgrass prairie once covered the area immediately below the escarpment. This is the 
southwesternmost extension of the Blackland Prairie physiographic region. An area of dense brush country forms a narrow band between the tallgrass prairie and the Oak-Hickory Forest of the southernmost section of the county, which is the northeastern boundary of the South Texas Plains (also called the Rio Grande Plains and the Tamaulipan biotic province [Blair 1950]). The fifth biotic zone is the riparian forest which cross-cuts all the other zones in the creek bottoms and around springs (Potter et al. 1995:23).

Each of these zones contains a somewhat different set of plant and animal communities, making the area an ecotone, and providing a wide diversity of resources (Collins 1995; Ellis et al. 1995; Nickels et al. 1997:4; Potter et al. 1995:13). In earlier times, Pecan (Carya illinoisensis), hickory (Carya sp.), walnut (Juglans sp.), and acorns (Quercus sp.) would have been plentiful in the late summer and fall, as would deer (Odocoileus virginianus), turkey (Meleagris gallopavo), and (at least by the Late Prehistoric period) javelina (Peccari tajacu) (Hulbert 1985; Potter et al. 1995:13; Tomka et al. 1997a). In upland regions, yucca (Yucca sp.), sotol (Dasylirion sp.), and prickly pear cactus (Opuntia sp.), the latter a year-round resource, were available. Rabbits, both cottontail (Sylvilagus sp.) and blacktailed jackrabbit (Lepus californicus), were an important resource (Tomka et al. 1997a; 1997b). Turtles and small fish were available in the creek bottoms (Tomka et al. 1997a).

In addition to plentiful water, plant, and animal resources, the region provided an important mineral resource: chert. Large quantities of high-quality chert eroded out of the limestone along ridges on the Balcones Escarpment, and the chert-bearing Uvalde gravels were available in the more southern parts of the county (Loomis et al. 1992; Nickels et al. 1997; Potter et al. 1992). No known chert outcrops, however, are located within the immediate vicinity of San Pedro Park.

\section{Paleoenvironment}

Understanding the environment within which people live is crucial to interpreting their cultural adaptations. Unfortunately, there is only enough paleoenvironmental data available to make very broad guesses about the climatic changes in the area around San Antonio. An extensive discussion of current research on the subject is available in Tomka et al. (1997a). Briefly, the Late Pleistocene environment was much cooler and wetter than today (Bryant and Holloway 1985:50). There is considerable disagreement about whether the change to the modern climate was a slow, steady warming and drying trend (Bryant and Shafer 1977:15-19), or was much more variable, with numerous fluctuations between relatively wet and dry periods throughout the Early and Middle Holocene, with the driest period between about 4000-6000 B.P. (Bousman 1994; Gunn and Mahula 1977). Evidence for a cooler, more mesic period about 2500 B.P. is fairly consistent, with dry periods at about $1600-1500$ B.P. and 500-400 B.P. (Bousman 1994; Tomka et al. 1997a).

Within the historic period, records allow a more finegrained examination of the climate. Norwine (1995:139) notes that the climate of South Texas is considered unusual or even unique among semi-arid environments. The extreme variability of rainfall and temperature, which exhibits very little in the way of periodicity or trend, can have considerable, if temporary, effect on the plant and animal communities in the region (Norwine 1995:139-140). However, a recent connection between the El Niño event in the South Pacific and wet, cool years in Texas has been identified (Stahl and Cleaveland 1995:60) and traced back 300 years in tree ring data (Stahl and Cleaveland 1993).

In addition to natural fluctuations in biotic communities, man-made changes have occurred as well. EuroAmerican land-use and water-use practices of the last 200 years have led to extensive changes in the plant and animal communities in the area around San Pedro Springs. Overgrazing and the control of wild fires have resulted in an expansion of brushy species, especially mesquite (Prosopis glandulosa), blackbrush acacia (Acacia rigidula), whitebrush (Aloysia gratissima), and huisache (Acacia smallii), from the mottes which they once inhabited to a position of dominance over both the tallgrass prairie and the chaparral regions of the county (Inglis 1964). Pumping water from the Edwards aquifer has depleted many springs and turned once permanent or semi-permanent streams into dry ditches through which water flows only when there are heavy rains (Brune 1981). 


\section{Previous Research}

Although the park has been recorded as a site (41BX19), and the area around San Pedro Springs has a rich and varied cultural heritage, little archaeology has been conducted within the immediate area. Surface collections indicate occupation of the springs in the San Antonio River valley since the Late Pleistocene (Fox 1975; Orchard and Campbell 1954). In 1977, CAR conducted limited excavations on a portion of the Alazán Acequia in the area to the east and north of the main springs (Fox 1978). Fox's excavation revealed a two-phase construction sequence. Fox has also noted other structures of possible historic or cultural value within the park (Fox 1979). Her excavation was the only professional excavation known to have taken place within the park itself until the shovel testing conducted in 1996 (Meissner et al. 1998).

In 1985 archival and archaeological investigations were conducted on nearby portions of the San Pedro acequia and a search was conducted for traces of the Arocha Acequia south of the park (Cox 1986). A section of the Alazán acequia was exposed and documented in the area of South Frio Street (Labadie 1987). In 1989, San Antonio River Authority contracted with CAR to identify cultural resources associated with the anticipated channel improvement for San Pedro Creek just south of the park, the Five Points intersection, and southward to Interstate Highway 10. An archival and historic research report was published which identified potentially sensitive areas within the project area (Uecker 1991). During a channel improvement project in 1996, an underground section of the Alazán acequia was encountered below the intersection of Cornell Street and Fredericksburg Road. This section was documented by Nickels and Cox (1996).

Most recently, CAR conducted shovel testing along the western edge of the park, adjacent to North Flores Street (Meissner et al. 1998). Those investigations documented high prehistoric artifact densities in the southwest corner of the park. In one shovel test, 234 flakes were encountered between 20 and $40 \mathrm{~cm}$ below the surface (bs). Other units yielded burned rock and faunal material. A backhoe trench excavated during that project located a section of the Alazán Acequia in the northwest corner of the park (Meissner et al. 1998).

\section{HISTORIC BACKGROUND}

\section{Prehistoric Period \\ Barbara A. Meissner}

The following is a brief summary of the prehistory in the area around San Pedro Springs. More detailed discussions of the prehistory of South and Central Texas are available in Collins (1995), Hester (1995), and Hunziker et al. (1997).

The archaeological evidence shows that Native Americans in the San Antonio area were huntergatherers who lived in small bands. As discussed above, the region is an ecotone, with a wide range of resources for its inhabitants. The many springs, creeks, and rivers in the area provided plenty of water, even in times of drought. In addition to food resources, the area contained large quantities of high-quality chert. Together, these resources made the San Antonio River valley a favorable location for hunter-gathers. There is evidence that Native Americans exploited those resources as early as 12,000-11,000 years ago (Black 1989; Collins 1995; Orchard and Campbell 1954). Occupation of the valley was probably continuous from that time to the present. Archaeological research has divided this long period into a few very general intervals, presented in Table 1.

There is no evidence that, prior to the coming of the Spanish, the inhabitants of the San Antonio valley ever become farmers, unlike their neighbors living to the east. As Collins (1995:387) states, 
Table 1. Prehistoric Cultural Intervals (based on Hunziker et al. 1997)

\begin{tabular}{|c|c|c|}
\hline Interval & $\begin{array}{c}\text { Approx. Dates } \\
\text { (B.P.) }\end{array}$ & Characteristics \\
\hline Paleoindian & $11200-8000$ & $\begin{array}{l}\text { Not well understood. Previously assumed to be largely focused on hunting big game, } \\
\text { but now believed to have included a variety of smaller game as well as plant foods. } \\
\text { Most known sites are on upland settings (valley margins, terraces, etc.) but a few } \\
\text { deeply buried sites have been found in valley bottoms. Typical diagnostic artifacts } \\
\text { include Clovis, Folsom, and Plainview projectile points in the early period and } \\
\text { Golondrina and Angostura in the later period. }\end{array}$ \\
\hline $\begin{array}{c}\text { Early } \\
\text { Archaic }\end{array}$ & $8000-5000$ & $\begin{array}{l}\text { Emphasis is presumed to have shifted from now-extinct large gregarious herbivores } \\
\text { to deer, smaller mammals, and increased use of plant foods, but little direct } \\
\text { subsistence data is available due to poor preservation of flora and faunal remains. } \\
\text { Sites are generally on terraces near water. There is a shift to more regional projectile } \\
\text { point types. Diagnostic artifacts include Uvalde, Martindale, Baker, Bell, and Andice } \\
\text { points, and probably the distinctive Guadalupe biface. }\end{array}$ \\
\hline $\begin{array}{l}\text { Middle } \\
\text { Archaic }\end{array}$ & $5000-2400$ & $\begin{array}{l}\text { There is apparently an increase in emphasis on intensive use of vegetal resources, as } \\
\text { evidenced by the very common presence of large accumulations of burned rock, as } \\
\text { well as manos and metates. Sites are on knolls and bluffs along stream channels. Most } \\
\text { common diagnostic artifacts include Pedernales, Langtry, Kinney, and Bulverde. } \\
\text { Tortugas, Morhiss, and Lange points appear late in the period. The first large } \\
\text { cemeteries appear in this period. }\end{array}$ \\
\hline Late Archaic & $2400-1150$ & $\begin{array}{l}\text { Sites are usually found near water sources and occur in all topographic settings. } \\
\text { Subsistence appears to have been more broadly based, exploiting a wide range of } \\
\text { plant and animal resources. Burned rock middens are less common, but manos and } \\
\text { metates remain common. Diagnosticartifacts includeCorner-tang bifaces and Montell } \\
\text { and Marcos dart points. In the later part of the period, Ensor and Frio points are } \\
\text { common. }\end{array}$ \\
\hline $\begin{array}{c}\text { Late } \\
\text { Prehistoric }\end{array}$ & $1150-350$ & $\begin{array}{l}\text { There is a shift to bow-and-arrow and be ginning of ceramic technology. Edwards and } \\
\text { Scallorn points are diagnostic of the period. About } 600 \text { B.P. there was a distinct shift } \\
\text { to contracting stem arrow points such as Perdiz and the use of alternately beveled } \\
\text { bifaces, associated with an increase of bison bones in archaeological sites. }\end{array}$ \\
\hline
\end{tabular}

efficient technologies for hunting and gathering prevailed and ... the plant and animal resource base was both rich and diverse. Central Texas was one of those places in the world where the labors and limitations of food production could be looked upon with disdain.

The largest group described by early Spanish visitors to this region were the Payaya, whose apparent territory extended from the San Antonio valley to the southwest for at least 40 miles (Campbell and Campbell 1985:37). The diary of the Terán expedition mentions them on the San Antonio River in 1692 and describes them as "docile and affectionate, and naturally friendly" (Hatcher 1932:14). The diary of Gregario de Salina Verona mentions visiting a settlement of Payaya at San Pedro Springs in 1693 (Foster and Jackson 1993). They are believed to have been speakers of a Coahuiltecan language (Goddard 1979:366-367). Unfortunately, the
Spanish were interested in changing Native American lifeways, not recording them (Campbell 1975:1). What little they did describe was incidental to other matters and biased by their ethnocentrism.

Ethnographic evidence gives us some information about the Native Americans living here in the early eighteenth century, but it would be a mistake to believe that the lifeways described by the first Spanish visitors to Texas were identical to the long-successful adaptations of their ancestors (Campbell 1975:1). In the 150 years before the first Spanish settlement in the San Antonio Valley, the Native Americans of South and Central Texas had undergone serious disruptions as a result of an influx of groups fleeing the disturbances caused by the Spanish in northern Mexico and New Mexico, and possibly by the European diseases that were spreading through the area in the latter part of the seventeenth century (Ricklis 1996:131-132). These displaced groups were "often fragmented, and their populations declined" (Campbell and Campbell 1985:1). 


\section{Historic Period \\ I. Waynne Cox}

\section{The Spanish Colonial Period}

San Pedro Springs was named by Antonio de San Buenaventura de Olivares and Isidro Felix de Espinosa in 1709. Fray Espinosa, the diarist of the expedition, recorded,

dimos en una acequia de agua muy poblada de arboles que era suficiente para un pueblo, y toda liena de tomas de aqua estar alta la acequia y colgadas las tierras pusimosle por nombre el aqua de S. Pedro [Foster 1995:99].

This passage was translated by Father Gabriel Tous (1930:5) as:

we came to an irrigation ditch, bordered by many trees and with water enough to supply a town. It was full of taps and sluices of water, the earth being terraced. We named it San Pedro Springs.

Tous's use of the phrase "irrigation ditch" to translate the Spanish acequia is understandable, as this is the current usage of the word. This translation has led some (see Foster 1995:99) to believe that either the indigenous population was already farming in the valley when the expedition arrived or that earlier Spanish settlers already were present. There is no evidence for either interpretation in any other text, or in the archaeological record. In fact, later in the same diary, Espinosa says nothing about an acequia, but mentions that San Pedro Creek was "sufficient for a mission" (Tous 1930:9). It seems reasonable to translate the word acequia in the above passage as "stream" or "creek."

In April 1718, the newly appointed Governor of Coahuila, Martín de Alarcón, crossed the Rio Grande with an entrada of 72 persons intent upon establishing a way station between the Rio Grande and the East Texas missions. On May 1, Alarcón selected an area near the San Pedro Springs for the location of his new presidio (Hoffman 1935:49). This constituted the founding of what would become the city of San Antonio. Beside the presidio, the first mission-San
Antonio de Valero, later to gain fame in its present location as the Alamo-was established. The exact location of neither site is recorded but both were in the vicinity of the springs, probably on the higher ground to the northeast (presidio) and south (the mission).

One of the diarists of the expedition described San Pedro Springs. "This place in which we find ourselves is pretty because of the trees that it has at its spring. The water is sweet and very fine ... The trees which the wood contains consist of pecans, mulberries, elms, and poplars, and there are also many grapevines" (Hoffman 1938:317).

In January 1719 , an acequia was constructed to serve the needs of the presidio and its small contingent of families. In 1722, the new Governor, Marquís de San Miguel de Aguayo, learned that a raging fire had swept through many of the frail structures of the presidio of Béxar. Sixteen of the soldiers' huts had been destroyed and others damaged. Worst of all, the granary, with 700 bushels of corn and all of the flour, had been lost. He immediately ordered that a new presidio be built, this time of "fire-proof" adobe. The new presidio was to be constructed farther to the south at the big bend of the river opposite the new site of Fray Olivares's mission (Chipman 1992:125).

In 1724 Brigadier Pedro de Rivera y Villalon was dispatched by the viceroy to inspect and evaluate the frontier defenses of New Spain. The tour lasted until June 1728 and covered over 8,000 miles. Among his recommendations were the reduction of the East Texas garrisons and the relocation of the three missions there to new sites on the Colorado River, near present-day Austin. Viceroy Antonio de Aviles, the Marquís de Casafuente, acting on the recommendations, reduced the presidios and moved the missions in July 1730. That location was not acceptable to Father Paredes, the guardian of the founding college of Querétero, and the missions were again moved, this time to the San Antonio River valley on March 5, 1731.

Another recommendation of Brigadier Rivera was that the frontier be settled with stable families, believing that "one permanent Spanish family would do more to hold the country than a hundred soldiers" (Chabot 1937:141). On March 9, 1731, 56 settlers from the 
Canary Islands arrived at the presidio to form the nucleus of the Villa of San Fernando de Bexar, the first civil settlement of Texas. The king awarded this new settlement the right to eight leagues of land as a town tract, with the land outside of the villa to serve as ejido or public land (Corner 1890:36). The springs of both San Pedro and the San Antonio River were within this public land.

As the villa grew, so did the demand for public land that could be irrigated. In August 1762, a group of 13 citizens petitioned the governor for land and water to be distributed as previously ordained. In their request, they claimed that "about the year of forty-five" the viceroy had ordered the previous governor to distribute the lands, but for unknown reasons, he had failed to comply. The governor, Angel de Martos y Navarrete, agreed that the request was valid and directed Geronimo Flores, who was "skillful in withdrawing water," to measure the lands proposed for the acequia. Flores reported that a channel could be constructed from a point on the river 5,853 varas (three miles) north of the villa that would pass through 5,000 varas (4428.4 acres) of irrigable land. The only obstruction that presented itself was a stretch of 150 varas (416.6 ft) "across the brow of the hill which is called 'Loma de la Vieja", (now known as Tobin Hill, to the immediate northeast of the park; Bexar Archive Translations, "Citizens to Navarrete," August 1762). The governor fully agreed with the proposal and submitted it to the viceroy, but for reasons unrecorded, the plan was not put into effect. Fourteen years later, citizens again petitioned the governor, Baron de Ripperda, for the additional land and water. The reason for this renewal of interest may have arisen from the fact that the villa was in the depth of a severe drought which began in 1771 and lasted for six years (Gunn et al. 1982:70).

Having satisfied himself that neither the villagers nor the clergy were against the project, the governor ordered that by January 29, 1776, all "resident Islanders and others present themselves before me, and those who wish to contribute to said ditch, therefore after having enlisted themselves, to commence same, each to commence with one peon and the necessary tools" (Corner 1890:20). Construction on the acequia began in July 1776, and by April 28, 1777, the acequia had reached the midpoint of its construction. To render the ditch operational for the planting season, the ditch was returned to the river, and a drawing was held to distribute the first 26 suertes, containing some 25,230 varas of land. (Spanish Archives [SA], Office of the Count Clerk, Bexar County Courthouse, Volume 3:318332). By March 1778, the remaining portion of the acequia was finished, "draining into the San Pedro Creek by a trough ... so that the residents located on the other side may avail themselves of its excess," and the drawing procedure was repeated to distribute the remaining suertes of land. One exception was that Francisco Xavier Rodriguez did not take part in the drawing. He had agreed to take a suerte and a half to the north of the ditch (SA Volume 3:327). The suerte selected by Rodriguez was described as:

measuring 471 varas [1308.3 ft] from the aqueduct or trough of the upper labor ditch up said ditch in a direction east to a point where it forms an acute angle, thence running west 281 varas $[780.5 \mathrm{ft}]$, thence down the San Pedro Creek to the trough which crosses it for the drainage of the upper ditch 249 varas [691.6 ft], thence with said ditch to place of beginning [City Council Minutes (CCM), Office of the City Clerk, City Hall, Volume C:194].

The aqueduct referred to first was located where the new ditch, the Upper Labor, crossed an ancient acequia for the Labor Alta de Santa María. The latter began at the springs and flowed along what is now San Pedro Avenue to the point mentioned (near the intersection of Maverick and Warren streets). From that point the old acequia joined the Upper Labor and ran to a point near Howard and Euclid streets, where it turned southeast to the west of Richmond Avenue and returned to the river at St. Mary's and Arden Grove (SA Volume 2:474, Volume 3:333; Institute of Texan Cultures, “Abstract Block 31, City Block 302," Stewart Title Company Collection). This ancient acequia is, most probably, the original channel excavated for the first site of the presidio near the springs (Cox 1987:2-3).

The Rodriguez grant encompassed the lower portion of what is now San Pedro Park. His descendant, Judge José María Rodriguez, claimed that Francisco had established a trading post upon the grant (Rodriguez 1961[1913]:24). On August 26, 1778, Vicente Flores requested and was granted the vacant land to the north of the Rodriguez tract (SA Volume 2:474). In June 1784, Don Francisco Arocha submitted a complaint to 
Governor Cabello charging that Vincente Flores and Francisco Xavier Rodriguez had failed to comply with the conditions of their grants by "not keeping their fences in good order" (CCM Volume C:194; City Rightof-way Office, Main Plaza Building, "ROW File, NCB 996," abstractor's note). The original owners were then dispossessed and the lands awarded to Arocha (CCM C:194, abstractor's note). Francisco Arocha's heir, José Nepomuceno Arocha, conveyed 177 acres "adjoining the little spring" to Alfred J. Shelby, who in turn, transferred the property to Samuel Augustus Maverick on December 5, 1846 (Bexar County Deed Records [BCDR], Bexar County Courthouse, Volume D2:171).

The northeast corner of what now constitutes San Pedro Park served as the closest hard-limestone quarry to the city until well into the nineteenth century. Although the exact date of the beginning of the quarry has not been determined, its proximity to the city may indicate Spanish colonial use. The limestone was removed from the high margin of exposed stone that extended into what is now known as Tobin Hill.

\section{San Pedro Park in the Nineteenth Century}

As a result of the annexation of Texas in 1845, disputes between Texas and Mexico that had been growing since the establishment of the Republic of Texas came to a head, and Mexico broke diplomatic relations with the United States. Anticipating the outbreak of hostilities, Brevet Colonel William Selby Harney, with three companies of the 2nd Dragoons, was dispatched to San Antonio as the vanguard of Brigadier General John Wool's Chihuahua Campaign (Cutrer 1996:3:466). Due to a lack of adequate quarters in town, a camp was established at the springs and named "Camp Crockett" (Bauer 1974:144-146; Smith 1963[1919]:I:270). Anxious to secure a permanent military presence, the city offered the land at the springs to the army, but the federal government refused on the grounds that the land was unhealthy and subject to attack from the high ground nearby (Crook 1967:26; Peyton 1946:85). The area later served as a campground for John Russell Bartlett's retinue before their departure to survey the limits of the territory acquired as a result of Mexico's defeat (Bartlett 1965:38).

As early as 1847, the city of San Antonio had sought to reclaim those lands to which it felt entitled under the now-missing Spanish grant. After many years in court, the case was decided in favor of the city and the entire eight leagues of land was awarded to the municipal government (Texas Supreme Court 1857:287-321). The city then took action to evict those it considered trespassers and sold off some of the lands to balance the city budget. At that time the city surveyor, François Giraud, was instructed to define the public park. Giraud completed his survey and reported to the city council.

I have the honor to report for your consideration the following reserves to be made by your honorable body on the city property . . . at the head of the San Pedro Creek, a square around the springs ... being 518 varas [1438.8 ft] from east to west and 550 varas [1527.7 ft] from north to south [CCM B:191].

The park was officially dedicated as a public square on November 6, 1852. Although various individuals would contest the city claim for the next 58 years, the boundaries have remained unchanged to the present (BCDR S1:280, U2:574, W2:312, 344:432).

During the ensuing years, the springs became increasingly popular as a place for public activities. In September 1854, a two-day county agricultural fair was held there (Crook 1967:27). The park was also the scene of a heated political rally staged for Governor Sam Houston during his unpopular campaign to defeat secession (Alamo Express, 8 October 1860). After his efforts proved to be unsuccessful, the park served as the containment area for the federal troops after the surrender of General Twiggs (War of the Rebellion 1901:VII:572-574).

When the city dedicated the park, there was an occupant residing on the land without legal title, John Jacob Duerler. Duerler and his wife Elizabeth immigrated from St. Gallen, Switzerland, in 1849 (Steinfeldt 1978:94). Duerler leased a portion of the land from the city, "all that portion of the public square of the San Pedro Creek, now covered by buildings or enclosures occupied by me, and said buildings being about 70 or 80 varas (195 to 222 feet) east of the San Pedro Springs" (BCDR Volume R1:443). This seems to indicate that Dueler was the occupant, if not the builder, of the "old fort" that stands today in the eastern portion of the park. During the period 1851-1864 the control of the park is unclear. Other than Duerler, William Muller and a Captain Stitch, at various times, advertised themselves 


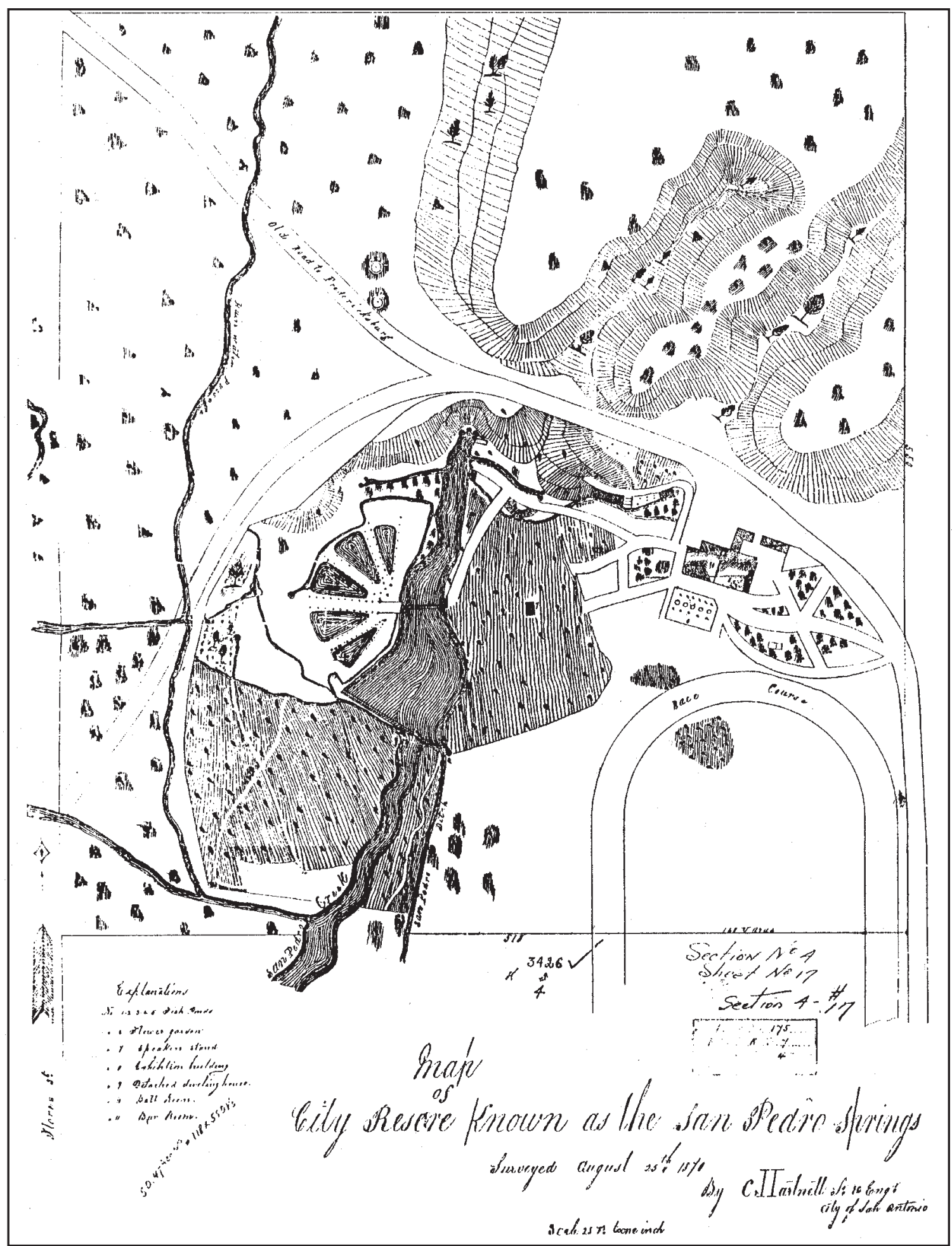

Figure 2. 1870 Map of the park. Dark blotches are springs.

as proprietors of the amusements at the springs. Finally, in March 1864, Duerler entered into a 20-year lease with the city for the exclusive operation of the concessions in the park. During the next decade, Duerler constructed five fan-shaped artificial lakes to the west of the natural lake at the head of the creek and stocked them with plants and colorful fish (Figure 2). These were shallow and fed by the several natural springs 
within the park (Allen 1993). He created a private museum and a collection of animals that was credited as being "the largest zoological collection in the South" (SAE, 18 March 1900). With the addition of a traveling animal show which became stranded in the city near the turn of the century and was purchased by the city council, Duerler's collection became the core of the San Antonio Zoo, which later moved to Brackenridge Park (San Antonio Light [SAL], 3 July 1949). Duerler also added a race course, an exhibition building, a ballroom, a tropical garden, and a lucrative and popular beer garden (Gould 1882:133).

In May 1874, the city council directed that work on the Alazán Ditch begin. The Alazán Ditch was a channel designed to provide both irrigation to the developing west side of the city beyond San Pedro Creek and flood relief from the storm waters of Olmos Creek that had often troubled the city (CCM Volume D:118; City Ordinance JD 372). The concept of the new acequia developed after a massive flood in the downtown section of the city in March 1865. The committee appointed to investigate the causes recognized that a major contributing factor was the substantial amount of water collected within the Olmos basin, then some five miles north of the city. The city engineer developed plans to divert this water away from the downtown area (CCM, C:475). Two years later, city engineer F. Giraud proposed diverting the flood waters of Olmos Creek to the Alazán Creek to the far west and south side of the city (CCM, Volume C:577, 583). No action was taken on the proposal at that time, no doubt due to the cost and complexity of the endeavor. The issue arose again in 1872 , when engineer C. Hartnett proposed to construct the diversion to the west, but this time including a plan to irrigate the lands west of San Pedro Creek (CCM, D:63-71). This was probably intended to provide the additional incentive of increasing land values to offset construction costs. Before any action was taken, Hartnett was replaced by G. Friesleben, who deemed the former's plan unworkable (CCM, D:111). Friesleben's revised plan for the ditch was approved by city council in May 1874, and construction began within four months.

Beginning at the confluence of Olmos Creek and the San Antonio River, the Alazán Acequia conveyed water through much of the old Upper Labor Acequia until it reached a point on San Pedro Avenue that had once served as a gate on the old acequia of the Labor Alta de Santa María. It then followed the old channel to the springs. From there a new channel was constructed to pass over the headwater of the springs to the right-ofway for the railroad and then south to the Alazán creek. The Alazán Acequia opened on June 9, 1875.

Problems with the ditch began almost immediately after its completion (CCM, Volume D:214), with evidence of poor construction and inadequate design (SAE, 17 April 1875, 5 May 1875). Apparently, these problems were primarily concerned with the necessity of raising the wall of the original Upper Labor portion of the new ditch to accommodate the additional flow from the waters of Olmos Creek.

In December 1876, the new city engineer, Louis Giraud, presented city council with yet another plan to correct the persistent design problems. The ditch was cut deeper near Fredericksburg Road, but this additional work did not seem to help the situation. In 1894 the citizens near the park petitioned the city council to declare it a public nuisance and have it filled. This was approved, and in May 1895, the city purchased 620 loads of dirt and had the ditch filled from where it departed the Upper Labor (CCM L: January 15, 1874, May 27, 1895).

In the mid-1880s the city authorized funds for further improvement in the park. Among these improvements was the construction of a "summer house" over one of the springs in the southeast portion of the park ( $S A L, 5$ May 1885). In 1891 the last overall concession ended and the city took control of all city parks. The city made several improvements at this time including the installation of electric lights and the baseball park in the southeast corner which replaced the racetrack. Several limited concessions were allowed under city contract, including the rental of small row boats for the lake. Between 1897 and 1899, the new administration made several major improvements to the park. Driveways were constructed, the fan-shaped pools were filled, and the lake was lined with masonry. The zoo was moved to the western portion of the park, and the summer house was replaced with a conical rock with a fountainhead which watered ferns in the rock cavities (SAE, 17 March 1900). 


\section{The Park in the Twentieth Century}

In the earliest part of the century, San Pedro Park continued to be a popular place to spend a summer Sunday. In 1915 the zoo was relocated to Brackenridge Park, and work was undertaken to address the problem of flooding of the homes near the park. The Sewer Construction Department began the excavation of a half-mile long channel constructed parallel to San Pedro Place (now Ashby Avenue) to the western margin of the park and draining to the south. The 30 -ft wide canal was five feet deep and its sloping sides were planted with grass. Pedestrian bridges were constructed across the canal. At this same time, a 36-inch concrete sewer pipe was installed to facilitate drainage into San Pedro Creek (SAL, 17 January 1915).

In 1922, under Commissioner Ray Lambert, a municipal swimming pool was constructed by cementing the original lake bed, with the bridge that spanned the lake retained across the pool (Allen 1993). At this time the flow of the spring was still sufficient to exchange the water three times daily (Crook 1967:78-80). The first branch library building was constructed in 1929, facing San Pedro Avenue. The San Antonio Little Theater (SALT) was begun the same year. The architect, Bartlett Cocke, replicated the Fries and Rossi Market house facade for the east face, using templates created by pressing sheets of lead onto the original, which was then stored in a city warehouse (San Antonio ExpressNews, 21 September 1986). The original swimming pool was closed in 1940 since the flow of the springs was no longer sufficient to provide adequate clean water. A new, small pool was opened in 1954 entirely dependent upon the city water supply. The McFarlin Tennis Courts were open the same year in the cavity of the old rock quarry (Crook 1967:95).

San Pedro Park continues to be a popular place in San Antonio. The tennis courts, the theater, the library, the baseball diamonds, and the swimming pool, as well as the open lawns and large shade trees, all serve as attractions.

\section{METHODS}

Eleven transects, designated A through $\mathrm{K}$, with a combined length of $870 \mathrm{~m}$, were established in areas scheduled to be impacted by future construction (Figure $3)$. Pedestrian surveys were conducted along the transects to locate any surface artifacts. After the pedestrian surveys, investigators initiated subsurface testing along the transects. Shovel tests were placed along the eleven transects at 20-m intervals, though in several areas this interval was reduced to $15 \mathrm{~m}$. Although 54 shovel tests were originally planned for the transects, the actual number excavated was 44 (Table 2). Along Transect D, ST 7 was placed but not excavated because the area was covered by a densely packed gravel pavement. Similarly, ST 33 on Transect G, 20 m south of ST 7, was planned but not completed because of the gravel pavement. The north end of Transect B crossed an asphalt access road and area previously disturbed by the installation of an underground drainage pipe. Two shovel tests were canceled from this transect. CAR personnel were unable to gain access to the area adjacent to the bathhouse. Transect K was therefore abandoned, and one shovel test on Transect $F$ was never placed or excavated. Most of this unsurveyed area was covered in asphalt, and as

Table 2. Shovel Test Transects

\begin{tabular}{|c|c|c|c|}
\hline Transect & Length & Planned STs & Excavated STs \\
\hline A & $75 \mathrm{~m}$ & 5 & 5 \\
\hline B & $75 \mathrm{~m}$ & 5 & 3 \\
\hline C & $88 \mathrm{~m}$ & 5 & 5 \\
\hline D & $62 \mathrm{~m}$ & 4 & 2 \\
\hline E & $46 \mathrm{~m}$ & 3 & 3 \\
\hline F & $33 \mathrm{~m}$ & 3 & 2 \\
\hline G & $130 \mathrm{~m}$ & 7 & 5 \\
\hline H & $262 \mathrm{~m}$ & 14 & 13 \\
\hline I & $38 \mathrm{~m}$ & 3 & 3 \\
\hline J & $38 \mathrm{~m}$ & 3 & 3 \\
\hline K & $23 \mathrm{~m}$ & 2 & 0 \\
\hline Totals & $870 \mathrm{~m}$ & 54 & 44 \\
\hline
\end{tabular}




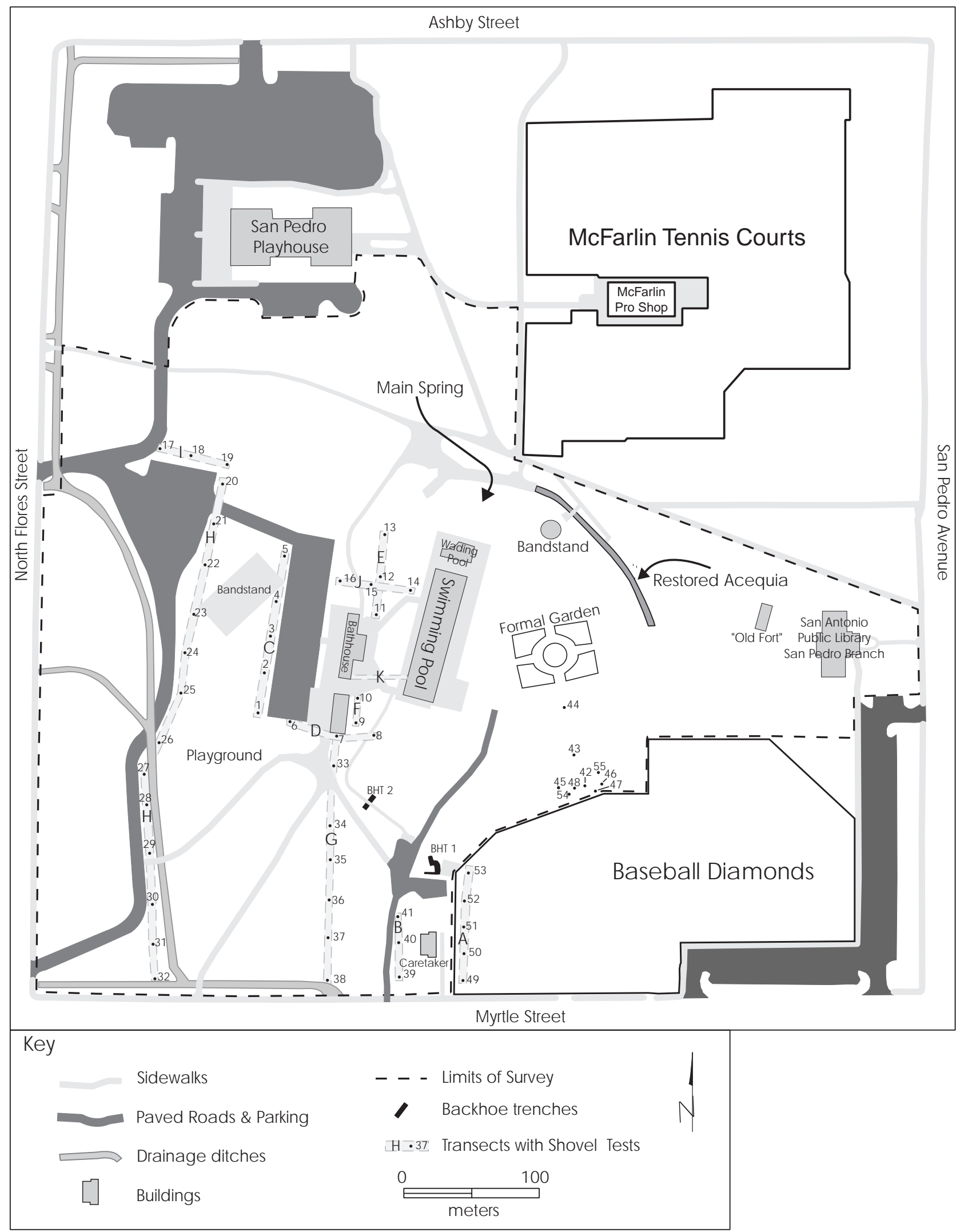

Figure 3. Map of park showing transects, STs, and BHTs. 
is discussed below, the entire bathhouse and pool area is one of the most disturbed sections of the park.

A larger area was also investigated by pedestrian survey (Figure 3). The pedestrian survey was conducted by a crew of four who walked the area on north-south transects, spaced approximately $10 \mathrm{~m}$ apart. Artifact concentrations were noted, but artifacts were not collected unless they were temporally diagnostic. Based on the high density of artifacts south of the Formal Gardens, an additional 10 shovel tests were excavated in this area.

Generally, shovel tests were excavated in 10-cm levels to a depth of $50 \mathrm{~cm}$, and the excavated matrix was screened through $1 / 4$-inch mesh. If artifact counts were high in the fifth level of a shovel test, a sixth level would be excavated. All cultural material, including modern debris, was collected from the shovel tests and returned to the CAR laboratory for processing and analysis. The soil or sediment, artifact contents, and degree of disturbance of each shovel test level was documented on a specially prepared form. Each shovel test was backfilled once the final level had been excavated.
The final stage of investigations required the excavation of backhoe trenches (BHTs) around the central pond to determine the location of the Colonial-age dam and gate to the San Pedro Acequia. Prior to this, a 1899 map of the park which depicted the original locations of sluice gate and diversion dam was examined. This map, features of which closely matched a 1986 Parks and Recreation Department map and the map for the current construction plan, suggested that the dam was in the vicinity of a modern sidewalk and that the sluice gate was located immediately north of the caretaker's house on Myrtle Street, west of the baseball fields. BHT 1 was excavated north of the caretaker's house to locate the sluice gate (see Figure 3 ). This trench was expanded to expose a larger area, and the resulting excavation was an irregularly shaped block. A second trench was excavated near the modern sidewalk in the suspected location of the Colonial dam (see Figure 3). To avoid destroying the sidewalk, BHT 2 was excavated in two sections: one on the north side and one on the south side of the sidewalk.

\section{RESULTS}

The results of the comparison of the 1899 and modern maps of the park, the pedestrian survey, the shovel testing, and the backhoe trenching are discussed below. The results of the analysis of the artifacts recovered during the project is reported in the appendix to this report.

\section{Comparison of Maps}

A copy of an 1899 map of the park was obtained by CAR from the Parks and Recreation Department. The map is labeled "E.G. Truehart, Detail fm [sic] City Engineers Map, San Pedro Park, June 23 $3^{\text {rd }} 1899$ " and depicts the area surrounding the springs and original pond. The map includes the locations of the five ponds constructed ca. 1870 west of the natural pond area, San Pedro Creek, the San Pedro Acequia, the Alazán
Acequia, and the bear's den from the private zoo. This map was overlaid on a current map of the park (Figure 4). As is evident, the 1899 map is extremely accurateit is possible to match the location of the old bear's den with that of the bandstand, and the Lower Pavilion with that of the Formal Garden. The location of the Alazán Acequia corresponds closely as well.

This overlay indicates that most of the area around the modern pool has been disturbed by previous construction activities. The area of the bathhouse represents the infilled, 1870s-era ponds. The area south of the modern pool, bounded on the west and south by a sidewalk and on the east by a service drive, is also artificially filled. 


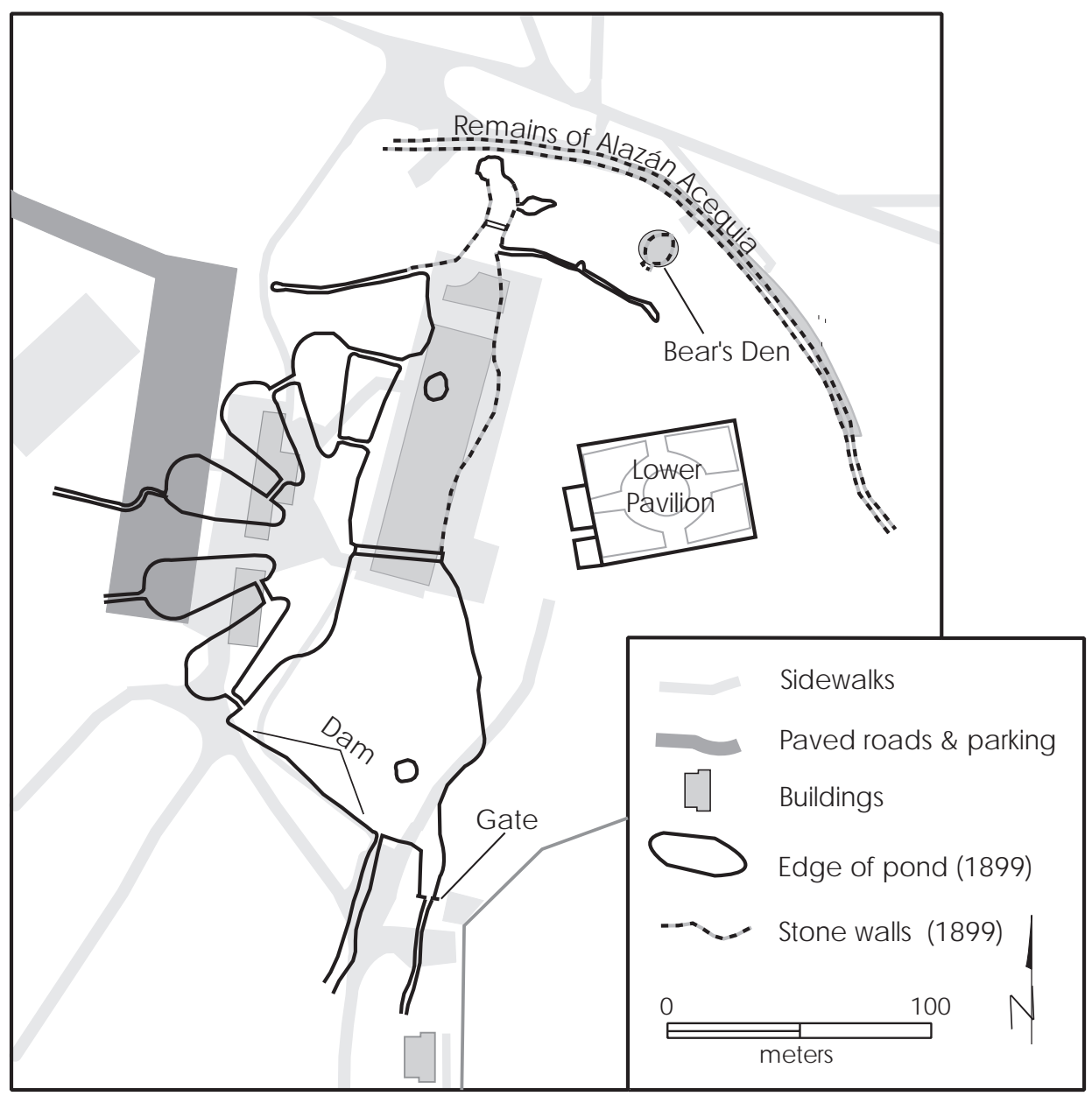

Figure 4. Overlay of 1899 map on current park map.

As previously discussed, the map overlay indicates that the original Colonial dam, at the southern end of the lake, is located approximately under a modern sidewalk. It also suggests that the sluice gate to the San Pedro Acequia is located north of the caretaker's house, immediately west of a modern concrete slab. This information was used to place the backhoe trenches discussed below.

\section{Pedestrian Survey}

The pedestrian survey included the southern portions of Quadrants I and II, and the northern portion of Quadrant III identified three areas, labeled A, B, and C, with prehistoric cultural remains (Figure 5). In general, surface visibility was poor because much of the park is covered in grass. In areas shaded by large oak trees, however, visibility ranged from 75 to 100 percent.
Area A, in the western section of the park (Figure 5), contained a fragment of burned bone and two chert flakes. Area B, located south of the formal garden, contained one early-stage biface, one chopper-like tool, one core, and approximately 10 chert flakes. Area C, located southwest of the Branch Library, contained a chert uniface, five flakes, and a lead-glazed ceramic sherd. None of the material noted from the three areas was collected. As is discussed below, nine shovel tests were excavated in Area B to assess the nature of the subsurface deposits.

No concentrations of historic artifacts were encountered during the survey. Modern refuse, however, is quite common. It is possible that historic artifacts found on the surface are routinely collected along with modern refuse by park employees who gather and dispose of trash daily. Additionally, one individual was observed 


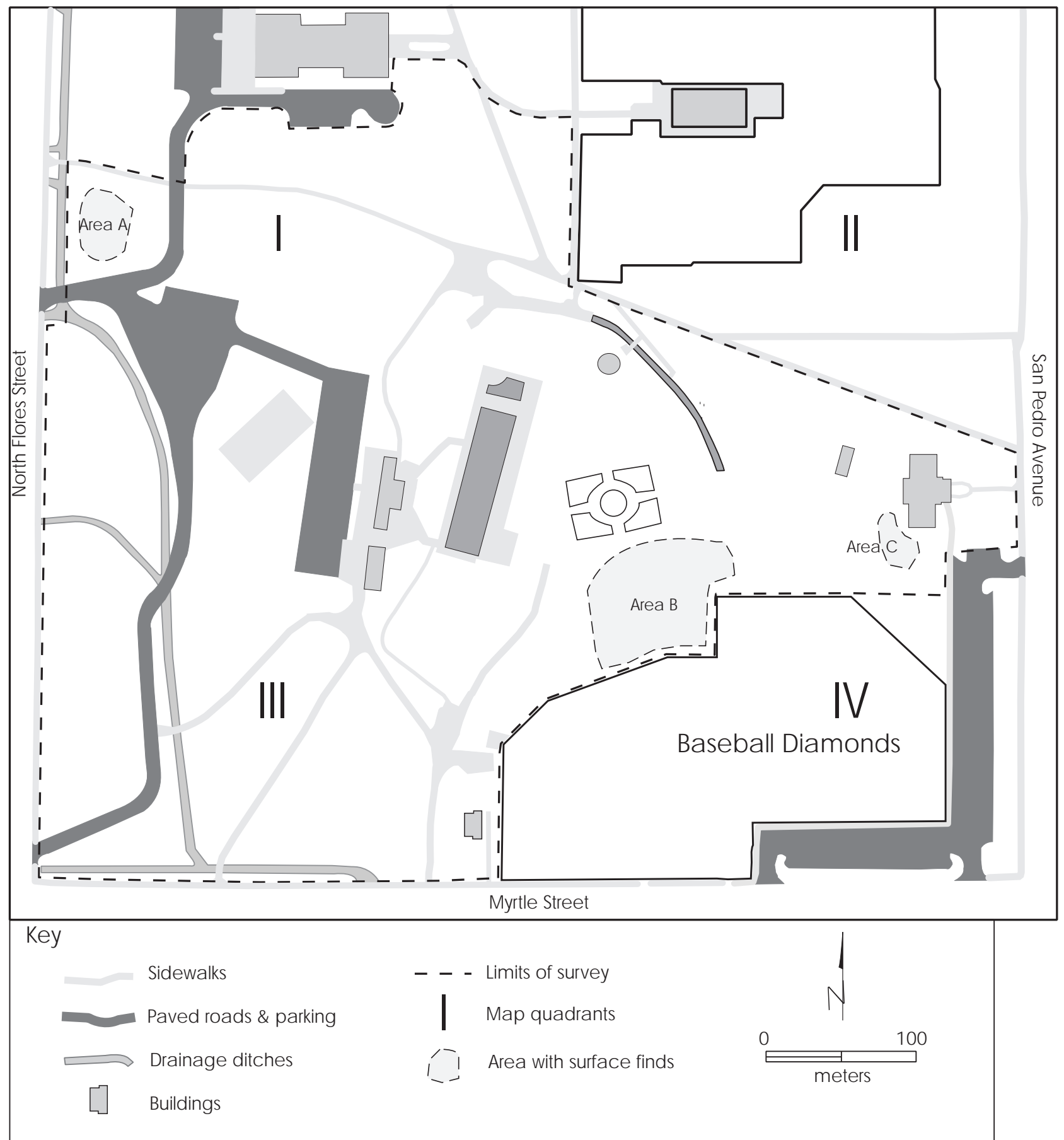

Figure 5. Survey results map with surface artifact scatters, Areas A-C.

using a metal detector to prospect for historic artifacts and coins in the park while the fieldwork was in progress.

\section{Shovel Tests}

The following discussion of the results of the shovel testing is organized by transect and area, not by shovel test number. This will facilitate management-related decisions with respect to particular impact areas. The 
shovel tests transects are discussed first, followed by the additional shovel tests excavated at Area B.

Table 3. Results of Transect A Shovel Tests

\begin{tabular}{|c|c|c|c|c|c|c|}
\hline \multirow[b]{2}{*}{$\begin{array}{c}\text { Shovel } \\
\text { Test }\end{array}$} & & \multicolumn{4}{|c|}{ Materials } & \multirow[b]{2}{*}{ Comments } \\
\hline & Level & $\frac{\tilde{g}}{0}$ & 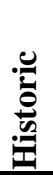 & 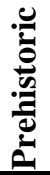 & & \\
\hline 50 & 4 & 4 & & 1 & & 3 FCR \\
\hline 50 & 5 & 43 & & 2 & & $4 \mathrm{FCR}$ \\
\hline 51 & 3 & 1 & & 1 & & \\
\hline 52 & 1 & 2 & & & & \\
\hline 52 & 3 & 3 & & 2 & & \\
\hline 52 & 4 & 2 & & 1 & & $1 \mathrm{FCR}$ \\
\hline 52 & 5 & 5 & & 1 & & \\
\hline 53 & 2 & 1 & 1 & 1 & & \\
\hline 53 & 3 & & 1 & 1 & & $1 \mathrm{FCR}$ \\
\hline 53 & 4 & 1 & 1 & & & \\
\hline 53 & 5 & & 1 & & & \\
\hline
\end{tabular}

Transect A, due to access problems, was the last transect investigated. This transect was located in the outfield of the west baseball field, approximately two meters from and parallel to the outfield fence. Five shovel tests, STs 49-53, were excavated at $20 \mathrm{~m}$ intervals along the transect (Table 3). Although historic and prehistoric materials were encountered in low densities, the high quantities of modern refuse in Levels 4 and 5 of STs 50,52 , and 53 indicate that the outfield has been heavily disturbed. ST 49 encountered a buried PVC pipe at 35 $\mathrm{cm}$ and had to be terminated.

Table 4. Results of Transect B Shovel Tests

\begin{tabular}{|c|c|c|c|c|c|c|}
\hline \multirow[b]{2}{*}{$\begin{array}{c}\text { Shovel } \\
\text { Test }\end{array}$} & \multicolumn{5}{|c|}{ Materials } & \multirow[b]{2}{*}{ Comments } \\
\hline & Level & 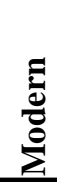 & 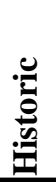 & 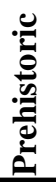 & 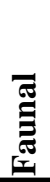 & \\
\hline 39 & 1 & 1 & & & 1 & \\
\hline 39 & 4 & 1 & & & & \\
\hline 41 & 1 & 16 & & & & \\
\hline 41 & 3 & & & 2 & & \\
\hline 41 & 4 & & 2 & 6 & & $1 \mathrm{FCR}$ \\
\hline 41 & 5 & 1 & & 3 & & \\
\hline
\end{tabular}

Transect B was located adjacent to the caretaker's house approximately three meters from the fence line. Although five shovel tests were planned for this transect, only three (STs 39-41) were excavated (Table 4). The north $30 \mathrm{~m}$ of the transect crossed an asphalt service drive and previously disturbed area. STs 39 and 40 appeared to be disturbed or entirely within construction fill. The northernmost unit, ST 41, had higher prehistoric artifact counts, but modern glass was encountered approximately $45 \mathrm{~cm}$ bs, suggesting this location is also highly disturbed.

Transect C was located approximately $1.5 \mathrm{~m}$ west of the bathhouse parking lot. Five shovel tests (STs 1-5) were excavated along this transect. ST 1 was abandoned at $35 \mathrm{~cm}$ when a buried telephone wire was encountered.

Table 5. Results of Transect C Shovel Tests

\begin{tabular}{|c|c|c|c|c|c|c|}
\hline \multirow[b]{2}{*}{$\begin{array}{c}\text { Shovel } \\
\text { Test }\end{array}$} & & \multicolumn{4}{|c|}{ Materials } & \multirow[b]{2}{*}{ Comments } \\
\hline & Level & $\frac{\Xi}{0}$ & 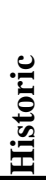 & 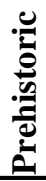 & 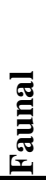 & \\
\hline 1 & 1 & 13 & & 2 & & \\
\hline 2 & 1 & 16 & 3 & & & \\
\hline 2 & 2 & 2 & 1 & & & \\
\hline 2 & 3 & 1 & 1 & & & \\
\hline 3 & 1 & 67 & & 1 & 4 & \\
\hline 3 & 2 & 23 & & & & \\
\hline 3 & 3 & 8 & & 4 & 1 & \\
\hline 3 & 4 & 3 & & & & \\
\hline 4 & 1 & 9 & 1 & 3 & & \\
\hline 4 & 2 & 2 & 1 & 1 & & \\
\hline 4 & 4 & & 3 & & & \\
\hline 4 & 5 & & & 1 & & \\
\hline
\end{tabular}

The data from these five units indicates that almost the entire transect has been disturbed to a depth of at least $40 \mathrm{~cm}$ bs (Table 5). In ST 4, two cut nails and one piece of window glass were recovered from Level 4 , and one multidirectional chert core was found in Level 5. This suggests that the disturbance in the area of ST 4 may be confined to the upper $30 \mathrm{~cm}$ of deposits, with possibly intact cultural levels located below that depth. ST 5, located near the junction between the parking lot and its entrance, encountered heavy gravels mixed in a clay loam matrix, presumably related to the construction of the parking area. 
Table 6. Results of Transect D Shovel Tests

\begin{tabular}{|c|c|c|c|c|c|c|}
\hline \multirow[b]{2}{*}{$\begin{array}{c}\text { Shovel } \\
\text { Test }\end{array}$} & \multirow[b]{2}{*}{ Level } & \multicolumn{4}{|c|}{ Materials } & \multirow[b]{2}{*}{ Comments } \\
\hline & & $\frac{\tilde{0}}{\frac{0}{0}}$ & 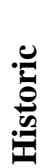 & 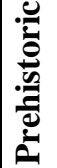 & 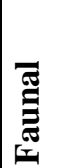 & \\
\hline 6 & 1 & 4 & 1 & & & \\
\hline 6 & 2 & 5 & & & & \\
\hline 6 & 4 & 4 & & & & \\
\hline 8 & 1 & 10 & & 1 & & \\
\hline 8 & 3 & 1 & & & & \\
\hline
\end{tabular}

Transect D joined the south end to Transect $\mathrm{C}$ at ST 1 and continued west, along the south edge of the bathhouse and its parking lot. ST 7 was marked along this transect but not excavated. The surface in this spot was a hard-packed gravel pavement. Two shovel tests (STs 6 and 8) were excavated to depths of $50 \mathrm{~cm}$ (Table $6)$. Both shovel tests encountered sparse cultural

Table 7. Results of Transect E Shovel Tests

\begin{tabular}{|c|c|c|c|c|c|c|}
\hline \multirow[b]{2}{*}{$\begin{array}{c}\text { Shovel } \\
\text { Test }\end{array}$} & \multicolumn{5}{|c|}{ Materials } & \multirow[b]{2}{*}{ Comments } \\
\hline & Level & 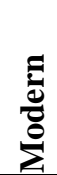 & 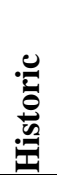 & 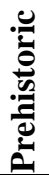 & 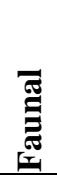 & \\
\hline 11 & 1 & 2 & & & & \\
\hline 11 & 2 & 32 & & 2 & & \\
\hline 11 & 3 & 9 & & & & \\
\hline 12 & 1 & 3 & & & & $1 \mathrm{FCR}$ \\
\hline 13 & 1 & 1 & & 1 & & \\
\hline 13 & 2 & & & 1 & & \\
\hline
\end{tabular}

material in disturbed contexts. An examination of the 1899 map of the park indicates that ST 8 was placed in the area once occupied by the lake see Figure 4). This area has since be filled and is therefore completely disturbed.

Transect E was located north of the bathhouse. STs 11 and 12 were spaced at $15 \mathrm{~m}$ apart. ST 13 was excavated $20 \mathrm{~m}$ north of ST 12. The artifacts from the Transect E shovel tests are primarily modern in age (Table 7). This area is almost entirely recent fill as indicated by the comparison of the 1899 map of the park to the modern project area (see Figure 4).
The north end of Transect F, a 33 m north-south transect with three planned shovel tests, was inaccessible and would have been on an asphalt surface. Two shovel tests, STs 9 and 10 were placed $15 \mathrm{~m}$ apart on the south end of the line and excavated to depths of $50 \mathrm{~cm}$. Both STs 9 and 10 were excavated through construction fill and were devoid of artifacts.

Table 8. Results of Transect G Shovel Tests

\begin{tabular}{|c|c|c|c|c|c|c|}
\hline \multirow[b]{2}{*}{$\begin{array}{c}\text { Shovel } \\
\text { Test }\end{array}$} & \multirow[b]{2}{*}{ Level } & \multicolumn{4}{|c|}{ Materials } & \multirow[b]{2}{*}{ Comments } \\
\hline & & 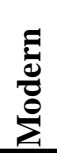 & 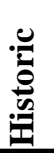 & 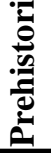 & 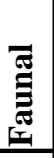 & \\
\hline 34 & 3 & 4 & & 1 & & \\
\hline 34 & 4 & 6 & & 1 & & \\
\hline 34 & 5 & 1 & & 1 & & \\
\hline 35 & 2 & 3 & & & 1 & \\
\hline 35 & 3 & 2 & & & & \\
\hline 35 & 4 & & & 1 & 1 & Core fragment \\
\hline 36 & 2 & 7 & & 1 & & \\
\hline 36 & 4 & 1 & & 4 & & \\
\hline 37 & 1 & 3 & & & 2 & \\
\hline 37 & 2 & 3 & & & & \\
\hline 37 & 4 & & 4 & & & \\
\hline 37 & 5 & 6 & & & & \\
\hline 38 & 2 & 6 & & & & \\
\hline
\end{tabular}

Transect $G$ intersected Transect D south of the bathhouse and terminated at a drainage channel adjacent to Myrtle Street. Six shovel tests (STs 33-38) were marked along this line, and all except for STs 33 and 38 were excavated to depths of $50 \mathrm{~cm}$. ST 33 was located on the same packed gravel pavement as ST 7, and ST 38 encountered a buried asphalt surface at 20 $\mathrm{cm}$ bs. In general, the units on this transect indicate that the area has been disturbed to a depth of at least 30 $\mathrm{cm}$ (Table 8). In STs 34 and 37 the depth of disturbance was at least $50 \mathrm{~cm}$ based on the presence of modern artifacts in the fifth excavation level. In ST 35, however, excavations encountered intact prehistoric deposits with low artifact densities in Level 4. This included one chert core fragment and one small fragment of animal bone.

The longest shovel test transect, Transect $\mathrm{H}$, paralleled an asphalt entry road and parking lot approximately 75 $\mathrm{m}$ west of the bathhouse. Thirteen shovel tests (STs 
20-32) were excavated along this $262 \mathrm{~m}$ line. The artifacts recovered from the shovel tests on this transect indicate that most of the line has been disturbed to a depth of at least $50 \mathrm{~cm}$ bs by prior construction related

Table 9. Results of Transect H Shovel Tests

\begin{tabular}{|c|c|c|c|c|c|c|}
\hline \multirow[b]{2}{*}{$\begin{array}{c}\text { Shovel } \\
\text { Test }\end{array}$} & \multirow[b]{2}{*}{ Level } & \multicolumn{4}{|c|}{ Materials } & \multirow[b]{2}{*}{ Comments } \\
\hline & & 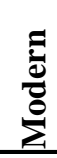 & 总 & 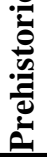 & 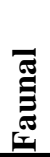 & \\
\hline 20 & 2 & & & 2 & & \\
\hline 20 & 3 & & & & 1 & \\
\hline 20 & 4 & & & & 2 & \\
\hline 21 & 1 & 2 & & 6 & & \\
\hline 21 & 3 & 1 & & 3 & & \\
\hline 21 & 4 & & & 1 & & \\
\hline 21 & 5 & & & 4 & & \\
\hline 23 & 1 & 1 & 3 & & & \\
\hline 23 & 2 & & & & 3 & \\
\hline 23 & 3 & 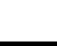 & & 1 & & \\
\hline 23 & 4 & & & 1 & & \\
\hline 24 & 1 & 2 & & & & \\
\hline 24 & 2 & 6 & & & 2 & \\
\hline 24 & 3 & & & 9 & & \\
\hline 25 & 1 & 9 & & 1 & 3 & \\
\hline 26 & 2 & 1 & & 1 & & \\
\hline 26 & 4 & 4 & & & 2 & \\
\hline 26 & 5 & 12 & & & & \\
\hline 27 & 3 & 2 & & 2 & & \\
\hline 27 & 4 & 5 & & 1 & & \\
\hline 27 & 5 & 5 & & & & \\
\hline 28 & 1 & 3 & & & & \\
\hline 28 & 2 & 4 & & 2 & & \\
\hline 28 & 4 & 1 & & 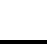 & & $1 \mathrm{FCR}$ \\
\hline 29 & 3 & 3 & & 1 & 1 & \\
\hline 29 & 4 & 12 & 1 & & 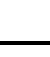 & \\
\hline 29 & 4 & 3 & & 1 & 1 & \\
\hline 30 & 1 & 7 & & 1 & & \\
\hline 30 & 2 & 2 & & 1 & & \\
\hline 30 & 3 & 1 & & & & \\
\hline 30 & 4 & 11 & & 3 & & \\
\hline 31 & 3 & 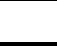 & & 2 & & \\
\hline 31 & 5 & & & 1 & & \\
\hline 32 & 1 & 2 & & & & \\
\hline 32 & 2 & 5 & & 1 & 1 & \\
\hline 32 & 3 & 2 & & 2 & 1 & \\
\hline 32 & 4 & 1 & & & & \\
\hline
\end{tabular}

activities (Table 9). Sections of the north end of the line, however, contain intact prehistoric deposits. In ST 20 , chert flakes and animal bone were recovered in Levels 2-3. Although ST 21 was disturbed through

Table10. Results of Transect I Shovel Tests

\begin{tabular}{|c|c|c|c|c|c|c|}
\hline \multirow[b]{2}{*}{$\begin{array}{c}\text { Shovel } \\
\text { Test }\end{array}$} & & \multicolumn{4}{|c|}{ Materials } & \multirow[b]{2}{*}{ Comments } \\
\hline & Level & $\frac{0}{0}$ & 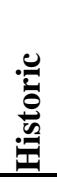 & 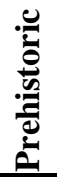 & 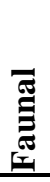 & \\
\hline 17 & 1 & 10 & & & & \\
\hline 18 & 1 & 13 & & & & \\
\hline 18 & 2 & 16 & & & 1 & \\
\hline 18 & 3 & 4 & & & 2 & \\
\hline 18 & 4 & 4 & & 2 & & \\
\hline 19 & 1 & 4 & & 1 & & \\
\hline 19 & 3 & 3 & & & & \\
\hline 19 & 4 & & & 2 & 2 & \\
\hline 19 & 5 & & & & 8 & FCR not collected \\
\hline 19 & 6 & & & 2 & 3 & 6 FCR \\
\hline
\end{tabular}

Level 3, one chert flake was recovered from Level 4 and four chips were recovered from Level 5. ST 22 was sterile, but STs 23 and 24 contained intact deposits below Level 3.

Transect I included STs 17-19 and was located near the north end of Transect $\mathrm{H}$, parallel to the edge of an asphalt parking lot. While STs 17 and 18 encountered disturbed deposits through Level 4, ST 19 encountered intact prehistoric remains in Levels 3-6 (Table 10). Materials recovered included fire-cracked rock, animal

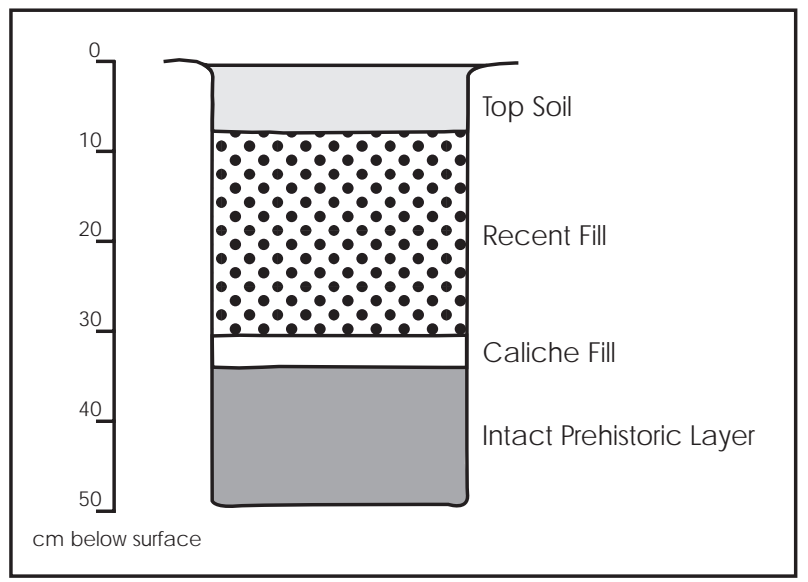

Figure 6. Profile of ST 19. 
bone, and chert flakes. There is apparently an intact prehistoric feature or midden in this location (Figure 6). ST 19 is approximately $15 \mathrm{~m}$ north of ST 20 , discussed above, which contained chert and animal bones in Levels 2 and 3.

Transect J intersected Transect E north of the bathhouse. STs 14-16 were located on this line. STs 14 and 15 are probably in previously disturbed areas, based on the data presented in Figure 4. While ST 14 encountered sandy fill to a depth of $50 \mathrm{~cm}$, ST 15 encountered seven

Table 11. Results of Transect J Shovel Tests

\begin{tabular}{|c|c|c|c|c|c|c|}
\hline \multirow[b]{2}{*}{$\begin{array}{c}\text { Shovel } \\
\text { Test }\end{array}$} & & \multicolumn{4}{|c|}{ Materials } & \multirow[b]{2}{*}{ Comments } \\
\hline & Level & $\frac{5}{0}$ & 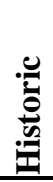 & 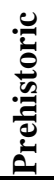 & 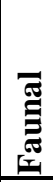 & \\
\hline 14 & 1 & 4 & & & & \\
\hline 15 & 1 & 2 & & & & \\
\hline 15 & 3 & 2 & & & & \\
\hline 15 & 4 & 2 & & & & \\
\hline 15 & 5 & & & & & $7 \mathrm{FCR}$ \\
\hline 16 & 1 & 7 & & 1 & & \\
\hline 16 & 2 & 2 & & 1 & & \\
\hline 16 & 3 & & & 1 & 6 & \\
\hline 16 & 4 & & & 3 & 2 & \\
\hline 16 & 5 & & & 20 & 4 & 2 Shell. 1 FCR \\
\hline 16 & 6 & & 2 & & 4 & $2 \mathrm{FCR}$ \\
\hline
\end{tabular}

small pieces of burned limestone in Level 5 (Table 11). No other cultural materials were recovered from this level, which was below the water table at the time the unit was excavated. At the west end of the transect, ST 16 encountered high prehistoric artifact counts in Level 5. One piece of historic glass and one sherd of historic ceramic were recovered from Level 6, suggesting that this location is also disturbed.

Transect K was a 23-m long line with two planned shovel tests. It was to be located within the fenced bathhouse and pool area, but CAR crews were unable to gain access through the locked gate. As will be discussed below, this area of the park has been seriously disturbed by modifications to the pool. Transect K, half of which crossed an asphalt surface, was therefore not surveyed.
Nine shovel tests (STs 42-48, 54, and 55) were excavated in Area B, the largest area of prehistoric artifact concentration encountered during the survey (Figure 3). Area B was chosen for further investigation through subsurface testing because of its close proximity to an area scheduled to be impacted. This area provided the best evidence for intact prehistoric deposits (Table 12). High artifact densities were

Table 12. Results of Area B Shovel Tests

\begin{tabular}{|c|c|c|c|c|c|c|}
\hline \multirow[b]{2}{*}{$\begin{array}{c}\text { Shovel } \\
\text { Test }\end{array}$} & & \multicolumn{4}{|c|}{ Materials } & \multirow[b]{2}{*}{ Comments } \\
\hline & Level & $\frac{\Xi}{0}$ & 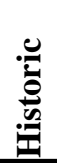 & 苞 & 氶 & \\
\hline 42 & 2 & 2 & & 3 & & \\
\hline 42 & 3 & & & 48 & 7 & $11 \mathrm{FCR}$ \\
\hline 42 & 4 & & & 36 & 4 & 14 FCR \\
\hline 42 & 5 & & & 8 & 23 & \\
\hline 43 & 4 & & & & & 43 FCR \\
\hline 44 & 1 & 2 & & & & \\
\hline 44 & 2 & 2 & & 1 & & \\
\hline 45 & 1 & & & 2 & & \\
\hline 45 & 2 & & & & 2 & \\
\hline 45 & 3 & & & 2 & & $6 \mathrm{FCR}$ \\
\hline 45 & 4 & & & 2 & & $3 \mathrm{FCR}$ \\
\hline 45 & 5 & & & 12 & & 15 FCR \\
\hline 46 & 2 & & & 6 & & 8 FCR \\
\hline 46 & 3 & & & & & $6 \mathrm{FCR}$ \\
\hline 47 & 1 & & & 7 & & $6 \mathrm{FCR}$ \\
\hline 47 & 2 & 3 & 1 & 5 & & \\
\hline 47 & 3 & & & 3 & & \\
\hline 47 & 4 & & & 5 & & $3 \mathrm{FCR}$ \\
\hline 47 & 5 & & & & & $2 \mathrm{FCR}$ \\
\hline 48 & 1 & 6 & & 7 & & \\
\hline 48 & 2 & & & 1 & & \\
\hline 48 & 3 & 20 & & 47 & 1 & \\
\hline 48 & 4 & & & 39 & 5 & 5 FCR \\
\hline 48 & 5 & & & 80 & 6 & $11 \mathrm{FCR}$ \\
\hline 54 & 1 & & & 1 & & \\
\hline 54 & 2 & 2 & & 1 & & \\
\hline 54 & 3 & 2 & 1 & 4 & & $3 \mathrm{FCR}$ \\
\hline 54 & 4 & & 1 & 8 & & $3 \mathrm{FCR}$ \\
\hline 54 & 5 & & & 1 & & 2 FCR \\
\hline 55 & 1 & 2 & & 2 & & \\
\hline 55 & 2 & & 1 & 61 & 7 & 17 FCR \\
\hline 55 & 2 & & & 12 & & 2 FCR \\
\hline 55 & 3 & & & 80 & 8 & 47 FCR \\
\hline 55 & 4 & & & 73 & 8 & 19 FCR \\
\hline
\end{tabular}


encountered in Levels 3-5 of STs 42, 45, 48, 54, and 55. The highest single artifact count came from Level 3 of ST 55 where 80 pieces of chert debitage, eight pieces of faunal material, and 47 pieces of fire cracked rock were recovered. One tool was recovered, a chert uniface, in ST 54 from below $40 \mathrm{~cm}$ in depth, but no temporally diagnostic artifacts were found. The investigations suggest that there is a small intact prehistoric burned rock midden at Area B. Burned rock middens are a common feature in central Texas and generally contain large amounts of fire cracked and discolored limestone. Other cultural materials are generally found within and around the accumulations of burned rock (Black 1989; Black et al. 1997).

\section{Backhoe Trench Excavations}

The initial placement of BHT 1 was based on the map overlay of the 1899 map and the modern park plan (see Figure 4). The overlay indicated that the gate to the San Pedro Acequia was located north of the caretaker's backyard fence and immediately west of a concrete slab. BHT 1 was excavated parallel to the fence line, beginning at the slab and extending eight meters to the west. It was anticipated that this trench would cut through the acequia, south of the gate.

The excavation encountered a cement-lined ditch, approximately $4.7 \mathrm{~m}$ wide (Figure 7 ). The walls of the ditch were composed of unfinished limestone blocks which had been coated in a $1 / 4$-inch to $1 / 2$-inch thick layer of sandy cement. The height of the walls was uneven but averaged approximately $60 \mathrm{~cm}$ on the west side of the ditch and one meter on the east. The floor of the ditch was covered by a 10-20 $\mathrm{cm}$ deposit of dark gray silty clay. This silty clay contained a small number of artifacts including a broken ceramic coffee cup and several broken bottles (two of which were Coca-Cola bottles). These artifacts date to the first half of the twentieth century. The rest of the trench was filled with construction debris composed of bricks, gravel, clay, unfinished limestone blocks, and displaced sections of the upper edge of the cement-lined ditch.

The trench was expanded to the north by following the east wall of the ditch with the backhoe. Eventually, the excavation was widened to reveal the architecture depicted in Figure 7. The excavations exposed what is believed to be a small spillway on the west side of the trench. The top of the spillway was apparently truncated by demolition, possibly during the infilling of the ditch. The fill in the north section of the trench included large limestone blocks, ceramic sewer pipe, gravel, sand, concrete, and clay.

The west wall of the ditch at the north end of the trench had been lined with cement. Rectangular outsets, approximately $47 \mathrm{~cm}$ high and $40 \mathrm{~cm}$ deep, were placed against the wall of the ditch after it had been lined. A 60 -cm-wide gap between the two exposed outsets had a $30-\mathrm{cm}$ vitrified ceramic pipe extruding from the base of the sloping surface where it met the floor of the ditch. Above this, a cast iron pipe measuring approximately $8 \mathrm{~cm}$ in diameter was set into the sloping surface, at the level of the top of the outset. The sides of the outsets in the gap had two centimeter wide notches which would have presumably held a sliding gate. The east side of the ditch had a similar outset, although its function is unknown.

Based on the map overlay (see Figure 4), this spillway and adjacent ditch are in the suspected location of the Colonial gate to the acequia. This feature does not appear on the 1899 map of the park, and the acequia was presumably closed in 1912 . We hypothesize that this spillway was constructed after the acequia was closed and is related to one of the renovations to the pond at the park. The Colonial gate and original channel of the acequia have apparently been destroyed by later construction activities. The modified channel was apparently filled ca. 1950 based on the age of the artifacts recovered from the silty clay deposit in the bottom of the ditch (see Appendix).

Alternatively, it is possible that the Colonial gate was actually located farther south. If this were the case, BHT 1 would have exposed the section of the acequia north of the gate. This would explain why the channel was so wide. Based on the accuracy of the 1899 map, however, it is more reasonable that the Colonial age construction has been destroyed.

The second trench, placed to locate the Colonial diversion dam at the south end of the lake, was 


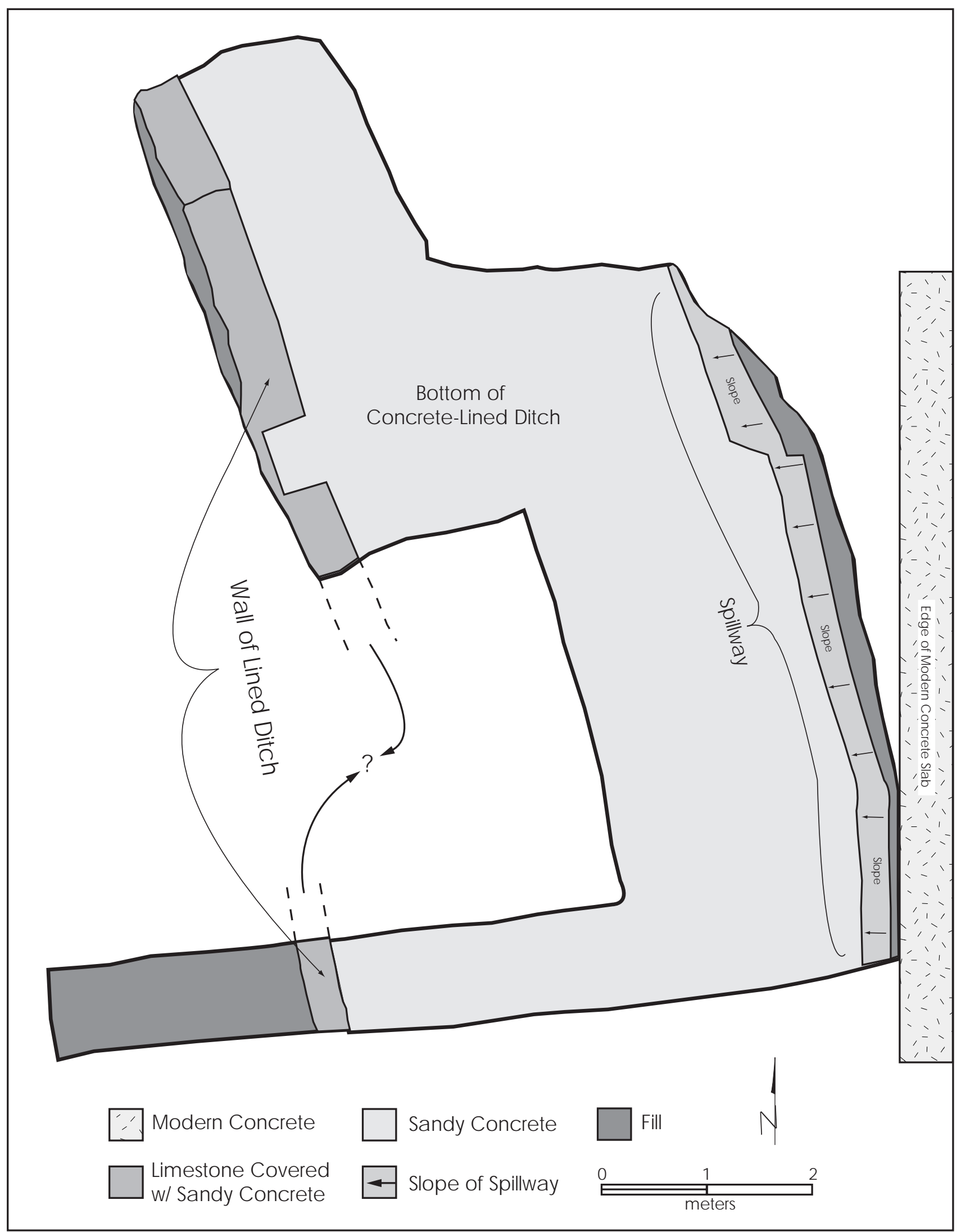

Figure 7. BHT 1, plan map. 
excavated in two sections (see Figure 3). The north section measured $0.7 \mathrm{~m}$ wide by $4.25 \mathrm{~m}$ long. It was excavated to a depth of $2.1 \mathrm{~m}$ at which point the backhoe encountered a cement slab. The matrix above this slab was mottled clay and represents artificial fill. The cement surface is presumably a lining that was placed on the bottom of the pond during the 1922 conversion of the pond to a swimming pool. Because the base of the trench was below the water table, it was too dangerous to enter the trench. A close inspection of the cement surface was therefore not possible.

A completely different matrix composed entirely of caliche gravel in the upper $60 \mathrm{~cm}$ was encountered in the south end of BHT 2. The fill overlay sterile black clay loam. BHT 2 measured $0.7 \mathrm{~m}$ wide by $3 \mathrm{~m}$ long (Figure 8). It was terminated at a depth of $80 \mathrm{~cm}$ bs. A 1-inch steel pipe was found parallel to the modern sidewalk approximately $10 \mathrm{~cm}$ bs. A concrete curb, possibly related to an earlier sidewalk, was found approximately $50 \mathrm{~cm}$ south of the pipe. The caliche gravel fill is obviously artificial and contained no artifacts. No evidence of the Colonial diversion dam was found in BHT 2, but it is possible that the dam, or sections of it, is preserved beneath the sidewalk.

Figure 8. BHT 2, plan and profile.

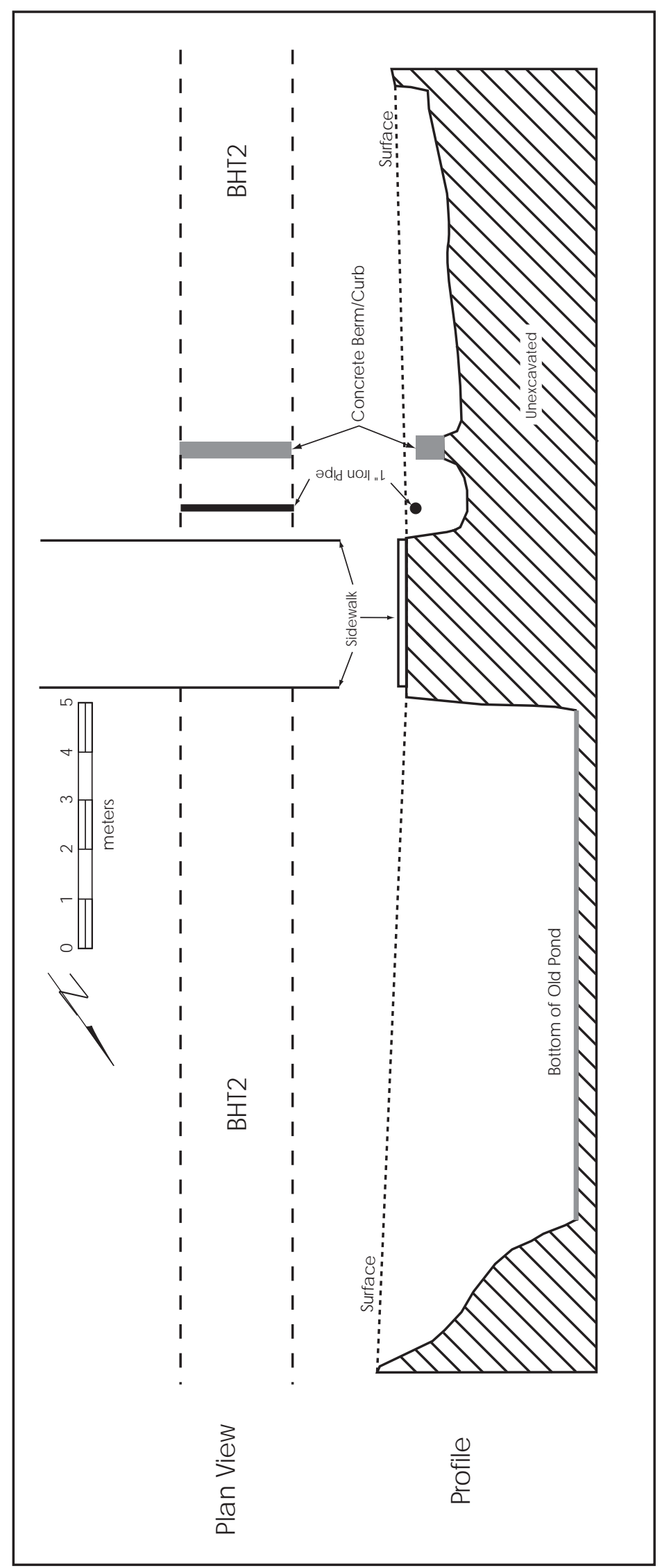


Based on the information collected during the pedestrian survey, shovel testing, and backhoe trench investigations, it is apparent that large sections of San Pedro Park are heavily disturbed, particularly in the vicinity of the modern pool and bathhouse. The comparison of the 1899 map of the project area indicates that this area represents infilled ponds or lakes and is therefore completely disturbed. The results from the 44 shovel tests excavated along transects A through J confirm that much of the park, including areas away from the ponds, is heavily disturbed. Most shovel tests encountered various forms of construction fill (i.e, sand, utility gravels, road bed, etc.) or contained modern materials such as metal, plastic, or glass in lower levels. Prehistoric remains were recovered, but were generally found in mixed context with modern materials.

There are isolated areas, including areas with intact prehistoric deposits and areas where possible historic structures may be impacted, which should be avoided during future construction activities. These areas, labeled Zones 1 to 6, are shown in Figure 9.

Zone 1, which corresponds with Area B (see Figure 5), originally identified during the surface survey and subsequently investigated with nine shovel tests. This area apparently includes a small burned rock midden buried approximately $20 \mathrm{~cm}$ bs. The exact dimensions of this feature were not determined, but it is probable that its current extent is limited to the south by the baseball field. Shovel tests along Transect A demonstrated that the outfield area has been heavily disturbed. Other impacts to the deposits include a shallow erosional channel that begins at the south end of the restored section of the Alazán Acequia. Both historic and prehistoric artifacts have been observed eroding from this channel (Meissner et al. 1998), and it is included in Zone 1. This area should be avoided is possible.

Zone 2, another area with intact prehistoric deposits is located near STs 19 and 20, in the northeast section of the project area. Although the upper $10-20 \mathrm{~cm}$ of deposits in this area have been disturbed, substantial intact cultural remains were encountered in these two units beginning at 30 and $20 \mathrm{~cm}$ bs, respectively. Approximately $40 \mathrm{~m}$ south of this area, STs 23 and 24 located intact deposits at $30 \mathrm{~cm}$ bs, although these were not as dense as in STs 19 and 20. In this area, impact below the depth of $20 \mathrm{~cm}$ should be avoided.

Zone 3 is centered around ST 35 on Transect G. This unit yielded a single artifact and a fragment of animal bone between 30 and $40 \mathrm{~cm}$ bs. The shovel tests to the north and south of this unit, however, encountered seriously disturbed deposits or culturally sterile material in all levels. In this area, impact below the depth of 30 $\mathrm{cm}$ should be avoided.

Zone 4 encompasses the southwestern portion of the park, where other archaeological investigations (Meissner et al. 1998) have documented intact and potentially significant prehistoric deposits. This area, though seriously disturbed by recent construction activities, contains areas of dense, intact prehistoric deposits (Meissner et al. 1998), and further destruction should be avoided.

The backhoe excavations north of the caretaker's house did not locate any evidence of the Colonial gate to the San Pedro Acequia. BHT 1 located a cement-lined ditch and small spillway in the approximate location of the original gate. This spillway is presumably related to the 1922 swimming pool, which was fed by the springs. We believe that the original acequia trench, which was closed ca. 1912, was modified for a short distance to catch and redirect overflow from the swimming pool into San Pedro Creek. The artifacts collected from the silty clay in the base of the ditch are consistent with a 1950s date for the infilling of the trench. Thus, the Colonial gate to the San Pedro Acequia has apparently been destroyed by later modifications to the channel. It is possible, however, that the gate is present south of the area investigated by BHT 1 . We recommend that any subsurface impacts in the area of the caretaker's house (Zone 5) be monitored by a professional archaeologist. 
The second trench, BHT 2, encountered a concrete slab $2.10 \mathrm{~m}$ below the surface. This is presumably the bottom of the 1922 swimming pool. Although no evidence for the Colonial dam was found, it is possible that sections of it are preserved under the existing sidewalk, which we have designated Zone 6 . We recommend that any impacts within the footprint of the sidewalk be monitored by a professional archaeologist.
We recommend that Zones 1-6 be avoided, if possible. If not, then we recommend that archaeological testing or mitigation should be conducted prior to construction. We recommend that the sponsor be allowed to proceed with the project as planned in areas not covered by Zones 1-6.

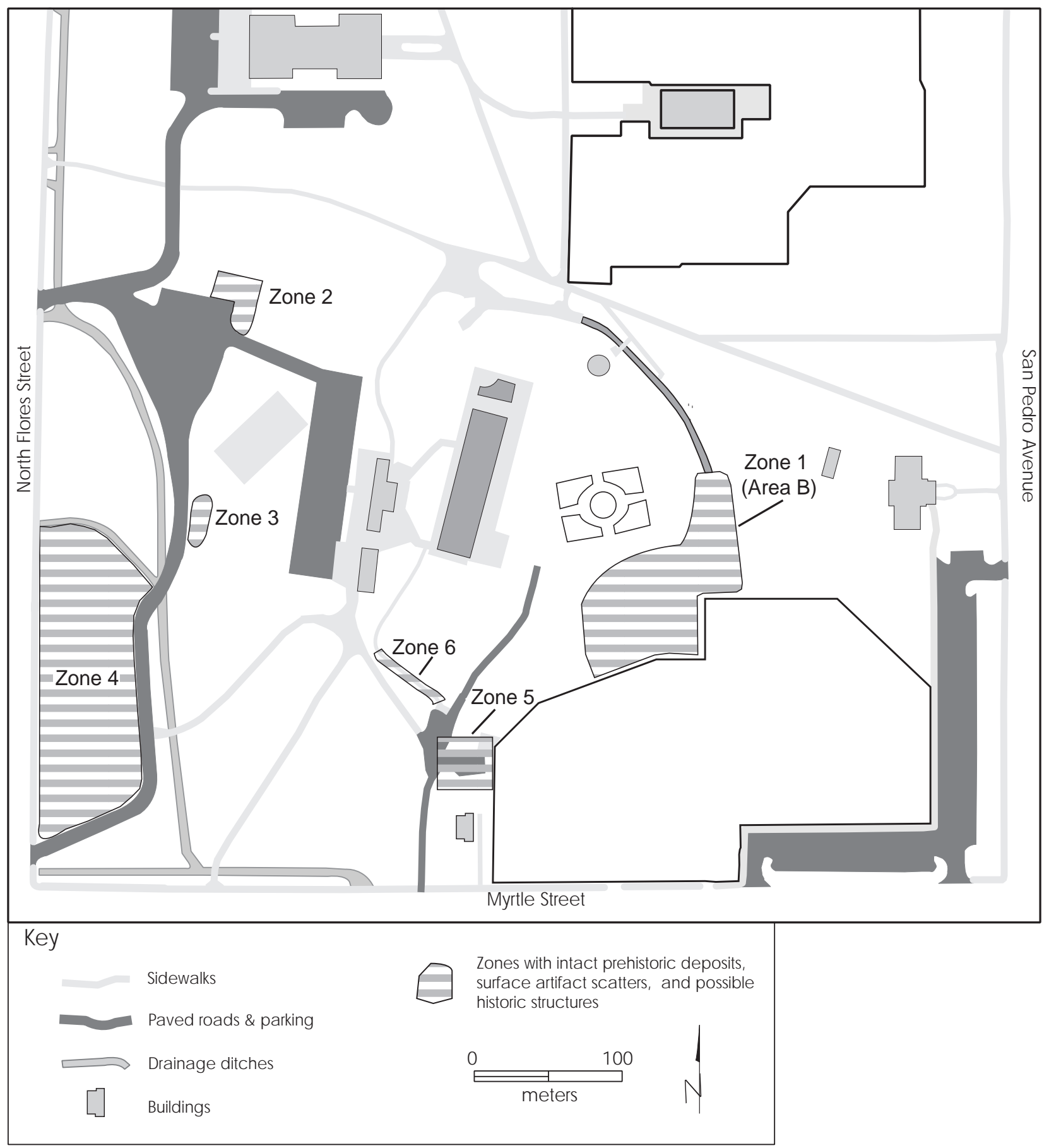

Figure 9. Map showing Zones 1-6, areas with intact prehistoric deposits or possible historic structures. 


\section{REFERENCES CITED}

Allen, P.

1993 Questionnaire. San Antonio Express-News, 15 August.

Alamo Express

1860 Governor's Address, 8 October.

Bartlett, J. R.

1965 Personal Narrative of the Expedition and Incidents Connected with the United States and Mexican Border Commission. Two Volumes. Originally published 1854, reprinted Rio Grande Press, Chicago.

Bauer, K. J.

1974 The Mexican War, 1846-1848. Macmillan, New York.

Black, S. L.

1989 Central Texas Plateau Prairie. In From the Gulf Coast to the Rio Grande: Human Adaptation in Central, South and Lower Pecos Texas, edited by T. R. Hester, S. L. Black, D. G. Steele, B. W. Olive, A. A. Fox, K. J. Reinhard, and L. C. Bement, pp. 17-38. Research Series No. 33. Arkansas Archeological Survey, Fayetteville.

Black, S. L. , L. W. Ellis, D. G. Creel, and G. T. Goode

1997 Hot Rock Cooking on the Greater Edwards Plateau: Four Burned Rock Midden Sites in West Central Texas. Studeies in Archeology No. 22, Texas Archeological Research Laboratory, The University of Texas at Austin, Archeology Studies Program No. 2, Texas Department of Transportation, Environmental Affairs Division, Austin.

Blair, W. F.

1950 The Biotic Provinces of Texas. Texas Journal of Science 1(1):93-117.

Bousman, C. B.

1994 The Central Texas Pollen Record: A Reinterpretation. Current Research in the Pleistocene 11:79-81.

Brune, G.

1981 Springs of Texas. Vol. 1. Branch-Smith, Fort Worth.

Bryant, V. M., and R. G. Holloway

1985 Late Quaternary Paleoenvironmental Record of Texas. In Pollen Records of Late-Quaternary North American Sediments, edited by V. M. Bryant and R. G. Holloway, pp. 39-70. American Association of Stratigraphic Palynologists Foundations, Austin.

Bryant, V. M., and H. J. Shafer

1977 The Late Quaternary Paleoenvironment of Texas: A Model for the Archaeologist. Bulletin of the Texas Archeological Society 48:1-25. 
Campbell, T. N.

1975 The Payaya Indians of Southern Texas. Special Publications No. 1. Southern Texas Archaeological Association, San Antonio.

Campbell, T. N., and T. J. Campbell

1985 Indian Groups Associated with Spanish Missions of the San Antonio Missions National Historical Park. Special Report, No. 16. Center for Archaeological Research, The University of Texas at San Antonio.

Chabot, F. C.

1937 With the Makers of San Antonio. Artes Gráficas, San Antonio.

Chipman, D. E.

1992 Spanish Texas, 1519-1821. University of Texas Press, Austin.

Collins, M. B.

1995 Forty Years of Archeology in Central Texas. Bulletin of the Texas Archeological Society 66:361-400.

Corner, W.

1890 San Antonio de Bexar: A Guide and History. Bainbridge and Corner, San Antonio.

Cox, I. W.

1986 Excavation of Portions of the San Pedro Acequia (41BX337) and a Search for the Arocha Acequia, San Antonio, Texas. Archaeological Survey Report, No. 161. Center for Archaeological Research, The University of Texas at San Antonio.

1987 Planning Document (Phase I) for Archaeological Investigations at Proposed Development at San Pedro Park. Letter Report, Center for Archaeological Research, The University of Texas at San Antonio.

Crook, C. E.

1967 San Pedro Springs Park, Texas Oldest Recreation Area. Privately printed, San Antonio.

Cutrer, T. W.

1996 Harney, William Selby. In The New Handbook of Texas, edited by R. Tyler, 3(466-467). Texas State Historical Association, Austin.

Ellis, L. W., G. L. Ellis, and C. D. Fredrick

1995 Implications of Environmental Diversity in the Central Texas Archeological Region. Bulletin of the Texas Archeological Society 66:401-426.

Foster, W. C.

1995 Spanish Expeditions into Texas, 1689-1768. University of Texas Press, Austin.

Foster, W. C., and J. Jackson (editors)

1993 The 1693 Expedition of Governor Salinas Varona to Sustain the Missionaries Among the Tejas Indians. Translated by N. F. Brierly. Southwestern Historical Quarterly 97:264-311. 
Fox, A. A.

1975 An Archaeological Assessment of the Southern Portion of the Olmos Basin, Bexar County, Texas. Archaeological Survey Report, No. 9. Center for Archaeological Research, The University of Texas at San Antonio.

1978 Archaeological Investigations of Portions of the San Pedro and Alazán Acequias in San Antonio, Texas. Archaeological Survey Report, No. 49. Center for Archaeological Research, The University of Texas at San Antonio.

1979 A Survey of Archaeological, Architectural and Historical Sites on the San Antonio River, from Olmos Dam to South Alamo Street and on San Pedro Creek from San Pedro Park to Guadalupe Street. Archaeological Survey Report, No. 80. Center for Archaeological Research, The University of Texas at San Antonio.

Goddard, I.

1979 The Languages of South Texas and the Lower Rio Grande. In The Languages of Native America: Historical and Comparative Assessments, edited by L. Campbell and M. Mithun, pp. 355-389. University of Texas Press, Austin.

Gould, S.

1882 The Alamo City Guide: San Antonio, Texas; Being a Historical Sketch of the Ancient City of the Alamo and Business Review. Macgowan and Slipper, New York.

Gunn, J., and R. Mahula

1977 Hop Hill: Culture and Climatic Change in Central Texas. Special Report, No. 5. Center for Archaeological Research, The University of Texas at San Antonio.

Gunn, J., D. O. Brown, A. A. Fox, A. Frkuska, and D. Watkins, III

1982 Historic and Cultural Landscape Study for the San Antonio Missions. Environmental and Cultural Services, San Antonio.

Hatcher, M. A. (translator)

1932 The Expedition of Don Domingo Terán de Los Rios into Texas. Preliminary Studies of the Texas Catholic Historical Society 2(1):20-78.

Hester, T. R.

1995 The Prehistory of South Texas. Bulletin of the Texas Archeological Society 66:427-459.

Hoffman, F. L. (translator)

1935 Diary of the Alarcán Expedition into Texas, 1718-1719. Quivira Society Publications, Volume 5. Reprinted, Arno, New York.

1938 The Mezquía Diary of the Alarcón Expedition into Texas 1718. Southwestern Historical Quarterly 41:312-323

Hulbert, R. C.

1985 Vertebrate Faunal Remains. In The Panther Springs Creek Site: Cultural Change and Continuity within the Upper Salado Creek Watershed, South-Central Texas, by S. L. Black and A. J. McGraw, pp. 209215. Archaeological Survey Report, No. 100. Center for Archaeological Research, The University of Texas at San Antonio. 
Hunziker, J. M., B. A. Meissner, S. A. Tomka, and T. K. Perttula

1997 Culture Histories and Their Use in the Archaeology of the Rio Grande Plains and the Central Coastal Plains. In Archaeology of the Rio Grande and Central Coastal Plains, Texas: A Planning Document, by S. A. Tomka, T. K. Perttula, and R. J. Hard. Archaeological Survey Report, No. 266. Center for Archaeological Research, The University of Texas at San Antonio. Review draft.

Inglis, J. M.

1964 A History of Vegetation on the Rio Grande Plain. Bulletin No. 45. Texas Parks and Wildlife Department, Austin.

Labadie, J. H.

1987 An Archaeological and Historical Assessment of the Vista Verde South Project, San Antonio, Texas. Archaeological Survey Report, No. 156. Center for Archaeological Research, The University of Texas at San Antonio.

Loomis, L. E., W. F. Gabriel, and B. R. Brasher

1992 Genesis of the Quihi Soil in the Uvalde Gravel of South-Central Texas. In Preliminary Draft of Late Cenozoic Alluvial Stratigraphy and Prehistory of the Inner Gulf Coastal Plain, South-Central Texas. Guidebook, 10th Annual Meeting, South-Central Friends of the Pleistocene. Lubbock Lake Landmark Quaternary Research Center Series 4:47-72.

Meissner, B. A., B. A., Houk, I. W. Cox, and O. Ford

1998 Archaeological Testing on the Western Edge and the Southwest Corner of San Pedro Park (41BX19), San Antonio, Bexar County, Texas. Archaeological Survey Report, No. 269. Center for Archaeological Research, The University of Texas at Austin. Draft report in preparation.

Nickels, D. L., and I. W. Cox

1996 An Archaeological Assessment of the Alazán Acequia (41BX620) in the Five Points Area of San Antonio, Bexar County, Texas. Archaeological Survey Report, No. 253. Center for Archaeological Research, The University of Texas at San Antonio.

Nickels, D. L., D. W. Pease, and C. B. Bousman

1997 Archaeological Survey of Lackland Air Force Base, Bexar County, Texas. Archaeological Survey Report, No. 248. Center for Archaeological Research, The University of Texas at San Antonio.

Norwine, J.

1995 The Regional Climate of South Texas: Patterns and Trends. In The Changing Climate of Texas: Predictability and Implications for the Future, edited by J. Norwine, J. R. Giardino, G. R. North and J. B. Valdez, pp. 138-154. Cartographics, Texas A\&M University. College Station.

Orchard, C. D., and T. N. Campbell

1954 Evidences of Early Man from the Vicinity of San Antonio, Texas. Texas Journal of Science 6(4):454465.

Peyton, G.

1946 San Antonio, City in the Sun. McGraw-Hill, New York. 
Potter, D. R., C. K. Chandler, and E. Newcomb

1992 Archaeological Salvage Research at 41BX901, a Prehistoric Quarry in Bexar County, Texas. Archaeological Survey Report, No. 211. Center for Archaeological Research, The University of Texas at San Antonio.

Potter, D. R., S. L. Black, and K. Jolly

1995 Archeology Along the Wurzbach Parkway. Module 1: Introduction, Conceptual Framework, and Contexts of Archeological Investigations in Bexar County, South-Central Texas. Studies in Archeology No. 17. Texas Archeological Research Laboratory, The University of Texas at Austin.

Ricklis, R.

1996 The Karankawa Indians of Texas. University of Texas Press, Austin.

Rodriguez, J. M.

1961[1913] Rodriguez Memoirs of Early Texas. Passing Show Press. Standard, San Antonio.

San Antonio Express [San Antonio, Texas]

1875 Ditch Contract Work, 17 April.

1875 Report of the Public Improvements Committee Upon the Upper Labor Ditch Contract Work, 5 May.

1900 San Pedro Park Improvements Complete, 17 March.

1900 San Pedro Park. 18 March.

San Antonio Express-News [San Antonio, Texas]

1986 San Antonio Little Theater. 21 September.

San Antonio Light [San Antonio, Texas]

1885 Park Improvements, 5 May.

1915 Large Canal in Park May Avert Floods, 17 January.

1949 The Zoo. 3 July.

Smith, J. H.

1963[1919] The War With Mexico, Two Volumes. Peter Smith, Gloucester, Massachusetts.

Stahl, D. W., and M. K. Cleaveland

1993 Southern Oscillation Extremes Reconstructed from Tree Rings of the Sierra Madre Occidental and Southern Great Plains. Journal of Climate 6:129-140.

1995 Texas Paleoclimate Data From Daily To Millennial Time Scales. In The Changing Climate of Texas: Predictability and Implications for the Future, by J. Norwine, J. R. Giardino, G. R. North, and J. B. Valdez, pp. 49-69. Cartographics, Texas A\&M University. College Station, Texas.

Steinfeldt, Cecilia.

1978 San Antonio Was: Seen through a Magic Lantern; Views from the Slide Collection of Albert Steves, Sr. San Antonio Museum Association, San Antonio.

Taylor, F. B., R. B. Hailey, and D. L. Richmond

1991 Soil Survey of Bexar County, Texas. United States Department of Agriculture, Soil Conservation Service, Washington, D.C. 
Texas Supreme Court

1857 Reports of Cases Heard and Decided, "Lewis, et al. v. City of San Antonio." Report Number 7, Texas Reports.

Tomka, S. A., C. B. Bousman, and J. M. Hunziker

1997a Modern and Paleoenvironmental Context. In Archaeology of the Rio Grande and Central Coastal Plains, Texas: A Planning Document, edited by S. A. Tomka, T. K. Perttula, and R. J. Hard. Archaeological Survey Report, No. 266. Center for Archaeological Research, The University of Texas at San Antonio. Review Draft.

Tomka, S. A., B. A. Meissner, and T. K. Perttula

1997b Hunter-gatherer Subsistence Practices. In Archaeology of the Rio Grande and Central Coastal Plains, Texas: A Planning Document, by S. A. Tomka, T. K. Perttula, and R. J. Hard. Archaeological Survey Report, No. 266. Center for Archaeological Research, The University of Texas at San Antonio. Review Draft.

Tous, G. (translator)

1930 The Espinosa-Olivares-Aguirre Expedition of 1709. Preliminary Studies of the Texas Catholic Historical Society, I (III).

Turner, E. S., and T. R. Hester

1993 A Field Guide to Stone Artifacts of Texas Indians. Second Edition. Gulf, Houston.

Uecker, H. G.

1991 Archival and Historical Research for the San Pedro Creek Channel Improvement Project: The 19891990 Investigations. Archaeological Survey Report, No. 199. Center for Archaeological Research, The University of Texas at San Antonio.

War of the Rebellion

1901 The War of the Rebellion, A Compilation of the Official Records of the Union and Confederate Armies. Volumes, Government Printing Office, Washington. 


\section{Methods}

The artifacts recovered during the shovel testing and backhoe trenching were washed and catalogued in the CAR laboratory. Modern debris such as glass, plastic, and pull-tabs was counted but not analyzed further. Historic artifacts were examined by Anne Fox. Prehistoric artifacts were classified into the following categories: complete flakes (subdivided into primary, secondary, and tertiary), incomplete flakes, cores, core fragments, tested cobbles, retouched flakes, formal unifaces, and bifaces (subdivided into early-, middle-, and late-stage reduction).

Complete flakes, defined as those with intact platforms and a measurable maximum length, were classified as either primary, secondary, or tertiary depending on the amount of cortex present on the flake's dorsal surface. Primary flakes have 100 percent cortex; secondary flakes have some cortex, but less than 100 percent; and tertiary flakes have no cortex. The incomplete flake category includes flakes which lack either a termination or a bulb of percussion, lateral flake fragments, chips of debitage, and chert shatter. Tested cobbles are defined as cores with a maximum of two flakes removed from one or two directions.

Flakes or flake fragments which had macroscopic evidence of having been retouched or modified on one or more edge were classified as retouched flakes. Formal unifaces are those tools with one or more edge that has been significantly shaped through the deliberate patterning of flake removals. Because use-wear analysis was not performed on the unifaces collected during this project, we have avoided using functional terms such as scraper or gouge. The term "retouched flake" has been used rather than "utilized flake" for this same reason.

Bifaces are artifacts on which flakes have been removed from both sides of the same lateral edge. Bifaces were subdivided based on their degree of reduction. Early stage bifaces are those which usually retain a small to large amount of cortex and have relatively few flake removals. The edges of these bifaces are generally very sinuous when viewed in profile. Middle-stage bifaces are typically thinner than early stage bifaces, have little or no cortex, and have numerous flake scars, many of which travel beyond the midline of the biface. The edges are less sinuous than those of early stage bifaces. Latestage bifaces are thin, have no cortex, and have numerous flake scars. Most of the flakes from late-stage bifaces have been removed by billet or soft hammer percussion. Flake scars are therefore longer and shallower than in early or middle-stage specimens. The edges of late-stage bifaces are usually straight when viewed in profile.

\section{Results of Analysis}

\section{Historic Artifacts from Shovel Testing}

The ceramics recovered are mostly British or Americanmade whitewares which probably date to the late nineteenth and early twentieth centuries. The one exception is a sherd of a type of earthenware made after 1810 in Guanajuato, Mexico. Although the colors and design on this sherd are similar to those on early nineteenth-century ceramics from that area, it could also date to the late nineteenth century, especially since there do not seem to be any other artifacts earlier than that in this collection.

The glass reflects the same time period as the whitewares. Most fragments are parts of whiskey, beer, soda, and other containers, with the majority being clear glass. The estimated earliest date would probably be 1903 when the first automatic bottle-making machines were used.

Modern bottle caps and can opening devices are liberally represented. These range from crown caps to aluminum pull tabs and ring tabs. Numerous fragments of rusted metal probably came from cans discarded in the area. 
Personal items probably dropped or discarded in the area include two pennies (1995 and 1996) and a dime (1982), two plastic comb fragments, a clothes pin spring, and two plastic buttons.

Numerous very small brick fragments, a lump of asphalt, and a few chunks of slag or cinders are the only miscellaneous artifacts collected. Of the nails recovered, seven are square cut which would have probably been installed before the 1880 s but could have arrived on the site at any time thereafter. The rest of the nails are common wire nails which, along with various screws and bolts, are relatively recent in manufacture.

The obvious conclusion is that there are no artifacts present that date to the Spanish colonial period of San Antonio's history, nor are there any that can be securely dated earlier than the last decade of the nineteenth century.

\section{Historic Artifacts from BHT 1}

The artifacts recovered from BHT 1 were found in the silty clay covering the bottom of the cement-lined ditch. They included primarily broken bottles. The fragments included pieces of two Coca-Cola bottle bases marked with "San Antonio, Tex", a mason jar, a baby bottle, a brown-glass bottle, and necks to two screw-top liquor bottles. Approximately fifty percent of a broken, white hotel-ware coffee cup with a simple green decorative pattern was found. Other artifacts included a marble and a carbon rod from a light or battery. The artifacts are unremarkable and are consistent in age with an infilling of the ditch ca. 1950.

\section{Prehistoric Artifacts from Shovel Testing}

The most apparent pattern in the prehistoric artifact data is that the assemblage is dominated by incomplete flakes which account for over 84 percent of the total (Table 13). Interestingly, of the 66 complete flakes recovered, 45 (68 percent) are tertiary and 20 (30 percent) are secondary. Although it was not quantified during the analysis, it was observed that most of the incomplete flakes were largely decorticate, as well. This pattern and the low frequency of cores, core fragments, and tested cobbles (1.4 percent of total artifacts) suggest that later-stage reduction of tools or tool rejuvenation were taking place. Initial reduction of raw material, which is not readily available in the vicinity of the park, was taking place elsewhere.

The artifact data and the large quantities of burned rock encountered in some shovel tests support the conclusion that the springs were used as campsites. Tools were finished or rejuvenated in the project area, but early stage reduction took place elsewhere.

No temporally diagnostic prehistoric artifacts were recovered from the shovel tests. The only formal tools included an early stage biface and a uniface. The uniface (Figure A-1) is made on a distal fragment of large chert flake. The dorsal surface of the uniface still retains a high percentage of cortex. The uniface is modified on both lateral edges and the distal end. It is $36 \mathrm{~mm}$ long (incomplete dimension), $38 \mathrm{~mm}$ wide at its widest point, and $12 \mathrm{~mm}$ thick at its thickest point. This uniface fits into the traditional category of end and side scraper based on its morphology (Turner and Hester 1993).

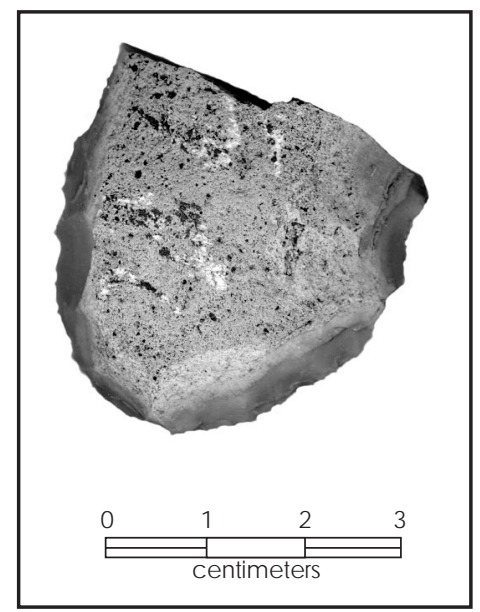

Figure A-1. Uniface. 
Table 13. Prehistoric Artifacts

\begin{tabular}{|c|c|c|c|c|c|c|c|c|c|c|c|c|c|}
\hline & & Com & lete $F$ & akes & & & & & & & & Bifaces & \\
\hline ST & Lvl & Prim. & Sec. & Tert. & $\begin{array}{c}\text { Incomp. } \\
\text { Flakes }\end{array}$ & Cores & $\begin{array}{l}\text { Core } \\
\text { Frags }\end{array}$ & $\begin{array}{c}\text { Tested } \\
\text { Cobbles }\end{array}$ & $\begin{array}{c}\text { Mod. } \\
\text { Flakes }\end{array}$ & $\begin{array}{l}\text { Formal } \\
\text { Unifaces }\end{array}$ & Early & Middle & Late \\
\hline 1 & 1 & & & & 2 & & & & & & & & \\
\hline 3 & 3 & & 1 & & 2 & & & & 1 & & & & \\
\hline 4 & 1 & & & & 3 & & & & & & & & \\
\hline 4 & 2 & & & & 1 & & & & & & & & \\
\hline 4 & 5 & & & & 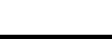 & & & & & & 1 & & \\
\hline 5 & 1 & & 1 & & & & & & & & & & \\
\hline 8 & 1 & & & & 1 & & & & & & & & \\
\hline 11 & 2 & & & 1 & 1 & & & & & & & & \\
\hline 13 & 1 & & & & 1 & & & & & & & & \\
\hline 13 & 2 & & & & 1 & & & & & & & & \\
\hline 13 & 4 & & & & 2 & & & & & & & & \\
\hline 16 & 1 & & 1 & & & & & & & & & & \\
\hline 16 & 3 & & & & 1 & & & & & & & & \\
\hline 16 & 4 & & & & 3 & & & & & & & & \\
\hline 16 & 5 & & 1 & 3 & 16 & & & & & & & & \\
\hline 18 & 4 & & & & 2 & & & & & & & & \\
\hline 19 & 1 & & & & 2 & & & & & & & & \\
\hline 19 & 6 & & & & 2 & & & & & & & & \\
\hline 20 & 2 & & 1 & & 1 & & & & & & & & \\
\hline 21 & 1 & & & 1 & 5 & & & & & & & & \\
\hline 21 & 3 & & & & 3 & & & & & & & & \\
\hline 21 & 4 & & & 1 & & & & & & & & & \\
\hline 21 & 5 & & & & 4 & & & & & & & & \\
\hline 23 & 3 & & & & 1 & & & & & & & & \\
\hline 23 & 4 & & & & 1 & & & & & & & & \\
\hline 24 & 3 & & & & 9 & & & & & & & & \\
\hline 25 & 1 & & & & & & & 1 & & & & & \\
\hline 26 & 2 & & & & 1 & & & & & & & & \\
\hline 27 & 3 & & & 1 & 1 & & & & & & & & \\
\hline 27 & 4 & & & & 1 & & & & & & & & \\
\hline 28 & 2 & & & & 2 & & & & & & & & \\
\hline 29 & 3 & & & & 1 & & & & & & & & \\
\hline 29 & 4 & & & & 1 & & & & & & & & \\
\hline 30 & 1 & & & & 1 & & & & & & & & \\
\hline 30 & 2 & & & & 1 & & & & & & & & \\
\hline 30 & 4 & & & & 3 & & & & & & & & \\
\hline 31 & 3 & & & 1 & 1 & & & & & & & & \\
\hline 31 & 5 & & & & 1 & & & & & & & & \\
\hline 32 & 2 & & & & 1 & & & & & & & & \\
\hline 32 & 3 & & & & 2 & & & & & & & & \\
\hline 34 & 3 & & & & 1 & & & & & & & & \\
\hline 34 & 4 & & & & 1 & & & & & & & & \\
\hline 34 & 5 & & & & 1 & & & & & & & & \\
\hline 35 & 4 & & & & & & 1 & & & & & & \\
\hline 36 & 2 & & & & 1 & & & & & & & & \\
\hline 36 & 4 & & & & 3 & & & & 1 & & & & \\
\hline 41 & 3 & & 1 & & 1 & & & & & & & & \\
\hline 41 & 4 & & & 1 & 4 & & & & & & & & \\
\hline 41 & 5 & & & & 3 & & & & & & & & \\
\hline
\end{tabular}


Table 13 (cont.). Prehistoric Artifacts

\begin{tabular}{|c|c|c|c|c|c|c|c|c|c|c|c|c|c|}
\hline & \multicolumn{3}{|c|}{ Complete Flakes } & \multirow[b]{2}{*}{$\begin{array}{c}\text { Incomp. } \\
\text { Flakes }\end{array}$} & \multirow[b]{2}{*}{ Cores } & \multirow[b]{2}{*}{$\begin{array}{c}\text { Core } \\
\text { Frags } \\
\end{array}$} & \multirow[b]{2}{*}{$\begin{array}{c}\text { Tested } \\
\text { Cobbles } \\
\end{array}$} & \multirow[b]{2}{*}{\begin{tabular}{c|} 
Mod. \\
Flakes \\
\end{tabular}} & \multirow[b]{2}{*}{$\begin{array}{c}\text { Formal } \\
\text { Unifaces } \\
\end{array}$} & \multicolumn{3}{|c|}{ Bifaces } \\
\hline ST & Lvl & Prim. & Sec. & Tert. & & & & & & & Early & Middle & Late \\
\hline 42 & 2 & & & & 2 & & & & & & & & \\
\hline 42 & 3 & & 1 & 3 & 44 & & & & & & & & \\
\hline 42 & 4 & & & 2 & 33 & & & & & & & & \\
\hline 42 & 5 & & 1 & 1 & 6 & & & & & & & & \\
\hline 44 & 2 & & & & 1 & & & & & & & & \\
\hline 45 & 1 & & & & 1 & & & 1 & & & & & \\
\hline 45 & 2 & & & & 2 & & & & & & & & \\
\hline 45 & 3 & & 1 & & 1 & & & & & & & & \\
\hline 45 & 4 & & 1 & & & & & & 1 & & & & \\
\hline 45 & 5 & & & 2 & 11 & & & & 1 & & & & \\
\hline 46 & 2 & & 1 & & 5 & & & & & & & & \\
\hline 47 & 1 & & & & 5 & & 1 & & 1 & & & & \\
\hline 47 & 2 & & & & 5 & & & & & & & & \\
\hline 47 & 3 & 1 & & & 2 & & & & & & & & \\
\hline 48 & 1 & & & & 5 & & & & & & & & \\
\hline 48 & 2 & & & & 1 & & & & & & & & \\
\hline 48 & 3 & & 2 & 1 & 31 & & & & 1 & & & & \\
\hline 48 & 4 & & 2 & 1 & 26 & & & 1 & - & & & & \\
\hline 48 & 5 & & & 2 & 76 & & & & 2 & & & & \\
\hline 50 & 4 & & & & 1 & & & & & & & & \\
\hline 50 & 5 & & & & 1 & & & & 1 & & & & \\
\hline 51 & 3 & & & 1 & & & & & & & & & \\
\hline 52 & 3 & & & & 2 & & & & & & & & \\
\hline 52 & 4 & & & & 1 & & & & & & & & \\
\hline 52 & 5 & & & & 1 & & & & & & & & \\
\hline 53 & 2 & & & & 1 & & & & & & & & \\
\hline 53 & 3 & & & & 1 & & & & & & & & \\
\hline 54 & 2 & & & & 1 & & & & & & & & \\
\hline 54 & 3 & & & 3 & 1 & & & & & & & & \\
\hline 54 & 4 & & & & 7 & & & & 1 & & & & \\
\hline 54 & 5 & & & & & & & & & 1 & & & \\
\hline 55 & 1 & & & & 2 & & & & & & & & \\
\hline 55 & 2 & & & 6 & 21 & 1 & & & & & & & \\
\hline 55 & 3 & & 5 & 3 & & & 1 & & 1 & & & & \\
\hline 55 & 4 & & & 8 & 65 & 1 & & & & & & & \\
\hline 55 & 5 & & & 3 & 9 & & & & & & & & \\
\hline
\end{tabular}

